INTERNATIONAL FOOD POLICY RESEARCH INSTITUTE

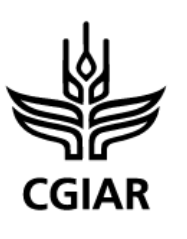
CGIAR
RESEARCH PROGRAM ON Policies, Institutions, and Markets Led by IFPRI
Schweizerische Eidgenossenschaft

Confédération suisse

Confederazione Svizzera

Confederaziun svizra

Swiss Agency for Development and Cooperation SDC

IFPRI Discussion Paper 01877

October 2019

\title{
Access to Markets for Smallholder Farmers in Alto Molócue and Molumbo, Mozambique \\ Mid-term Impact Evaluation of INOVAGRO II
}

Hosaena Ghebru

Jennifer Smart

Tewodaj Mogues

Development Strategy and Governance Division 


\section{INTERNATIONAL FOOD POLICY RESEARCH INSTITUTE}

The International Food Policy Research Institute (IFPRI), established in 1975, provides research-based policy solutions to sustainably reduce poverty and end hunger and malnutrition. IFPRI's strategic research aims to foster a climate-resilient and sustainable food supply; promote healthy diets and nutrition for all; build inclusive and efficient markets, trade systems, and food industries; transform agricultural and rural economies; and strengthen institutions and governance. Gender is integrated in all the Institute's work. Partnerships, communications, capacity strengthening, and data and knowledge management are essential components to translate IFPRI's research from action to impact. The Institute's regional and country programs play a critical role in responding to demand for food policy research and in delivering holistic support for country-led development. IFPRI collaborates with partners around the world.

\section{AUTHORS}

Hosaena Ghebru (Hosaena.Ghebru@cgiar.org) is a Research Fellow in the Development Strategy and Governance Division of the International Food Policy Research Institute (IFPRI), Addis Ababa, Ethiopia.

Jennifer Smart (j.smart@cgiar.org) is a Senior Research Analyst in the Development Strategy and Governance Division of IFPRI, Washington, DC.

Tewodaj Mogues (TMogues@imf.org) was a Senior Research Fellow in the Development Strategy and Governance Division of IFPRI, Washington, DC, when she primarily contributed to this work. She is currently a Senior Economist and Technical Assistance Advisor at the International Monetary Fund (IMF), Washington, DC.

\footnotetext{
Notices

${ }^{1}$ IFPRI Discussion Papers contain preliminary material and research results and are circulated in order to stimulate discussion and critical comment. They have not been subject to a formal external review via IFPRI's Publications Review Committee. Any opinions stated herein are those of the author(s) and are not necessarily representative of or endorsed by IFPRI.

${ }^{2}$ The boundaries and names shown and the designations used on the map(s) herein do not imply official endorsement or acceptance by the International Food Policy Research Institute (IFPRI) or its partners and contributors.

${ }^{3}$ Copyright remains with the authors. The authors are free to proceed, without further IFPRI permission, to publish this paper, or any revised version of it, in outlets such as journals, books, and other publications.
} 


\section{Contents}

Abstract $\quad$ iv

Acknowledgments $\quad \mathrm{V}$

Executive Summary

1. Introduction 1

2. InovAgro Market Development Approach 3

3. Data and Methodology 9

4. Descriptive Results 14

6. Concluding Remarks 30

$\begin{array}{ll}\text { References } & 31\end{array}$

\section{Tables}

Table 3.1. Study area and sample size 11

Table 4.1. Percentage of households that received information about input markets from any source 14

Table 4.2. Source from which information was received about input markets 14

Table 4.3. Implication of InovAgro on access to information about input markets 15

Table 4.4. Households' stated effects of having received input market information on their behavior 15

Table 4.5. Reasons why input market information did not affect households' decisions 16

Table 4.6. Percentage of households that received information about output markets from any source 17

Table 4.7. Source from which information was received by households about output markets 17

Table 4.8. Implication of InovAgro on access to information about output markets 17

Table 4.9. Households' stated effects of having received output market information on their behavior 18

Table 4.10. Reasons why output market information did not affect households' decisions 19

Table 4.11. Implication of InovAgro on access to extension services 20

Table 4.12. Implication of InovAgro on smallholder farmers' input market integration 20

Table 4.13. Implication of InovAgro on smallholder farmers' output market integration 21

Table 4.14. Implication of InovAgro on livelihood diversification 22

Table 4.15. Comparisons between treatment and control communities: Short-term outcome indicators 23

Table 4.16. Comparisons between the baseline and midline surveys: Long-term outcome indicators 25

Table 5.1. Impact of the InovAgro II project on short-term outcome indicators 27

Table 5.2. Impact of the InovAgro II project on long-term outcome indicators 29

\section{Figures}

Figure 2.1. Theory of change of the InovAgro project 


\section{ABSTRACT}

The Innovation for Agribusiness (InovAgro) project, which launched with its first three year phase in 2010, uses a market system development (MSD) approach towards the goal of increasing incomes of men and women small-scale farmers in northern Mozambique. InovAgro interventions promote improved agricultural productivity, participation in selected high-potential value chains and the development of inclusive and sustainable market systems, such that impacts are expected to last long beyond the termination of the project.

This paper presents results from a midline quantitative impact evaluation of the second phase of the InovAgro project interventions (2014-2017). In it, we use a carefully designed and executed quasiexperimental study design to credibly attribute changes in market engagement and welfare of participating farmers to exposure to the InovAgro II project, identifying and testing in what respects the intervention was most successful, and what regard it had less impact. Although InovAgro II projects operate in 11 districts of Zambézia and Cabo Delgado provinces, this impact evaluation focuses on two districts in Zambézia province (Alto Molócue and Molumbo), and in terms of value chains, focuses on the soybean and pigeon pea high-potential value chains, while the InovAgro II project interventions focus on these in addition to maize, sesame and groundnut. A baseline survey was undertaken in 2015 covering the 2014/2015 agricultural season and a midline follow-up survey was conducted in 2017, covering the 2016/2017 agricultural season and reaching 1,749 households of the original 1,886 households interviewed in the baseline survey.

Using difference-in-difference estimation and propensity score matching, we find that exposure to the InovAgro II project is associated with an increase in the proportion of households selling soybean and pigeon pea by approximately $5 \%$ and $16 \%$, respectively (significant at the .01 level). Exposure to the InovAgro II project also results in significantly higher shares of smallholder farmers using improved seed for soybean and pigeon pea (an increase of $6 \%$ for soybean and $2 \%$ for pigeon pea). We find that the InovAgro II project is also associated with significant increases in access to agricultural output market information from formal sources (5\%) and hired labor for farming activities (8\%). Despite the significant impacts on short term outcome variables, exposure to the InovAgro II project had limited impact on long term outcome variables, such as on rural-urban migration as well as engagement in the non-farm sector (two proxies for assessing potential welfare implications of the project) however this finding is not surprising given the impact evaluation covers only two years - a short period of time to bring about the long-term impacts expected to eventually emanate from an MSD project.

Keywords: smallholders; farmers; agricultural extension; access to information; agricultural production; supply chain; crop production; farmers associations; impact assessment; surveys 


\section{ACKNOWLEDGMENTS}

This work was undertaken as part of the CGIAR Research Program on Policies, Institutions, and Markets (PIM) led by the International Food Policy Research Institute (IFPRI). Financial support for this study was provided by the Swiss Agency for Development and Cooperation (SDC). This paper has not gone through IFPRI's standard peer-review procedure. The opinions expressed here belong to the authors, and do not necessarily reflect those of SDC, PIM, IFPRI, or the CGIAR.

The PIM program leads action-oriented research to equip decisionmakers with the evidence required to develop food and agricultural policies that better serve the interests of poor producers and consumers, both men and women, combining the resources of CGIAR centers and numerous international, regional, and national partners. www.pim.cgiar.org. 


\section{EXECUTIVE SUMMARY}

This paper presents preliminary results from an impact evaluation of the second phase of Innovation for Agribusiness (InovAgro II) project's interventions in northern Mozambique. The InovAgro project is funded by the Swiss Agency for Development and Cooperation (SDC) and implemented by Development Alternatives Inc. (DAI) in partnership with COWI . Data from two rounds of panel surveys - collected by the International Food Policy Research Institute (IFPRI) - were employed in the impact evaluation: the baseline survey undertaken in 2015 covering the 2014/2015 agricultural season and the midline survey undertaken in 2017 covering the 2016/2017 agricultural season. Although InovAgro projects operate in 11 districts - namely Mocuba, Ile, Namarroi, Molumbo, Gurúe and Alto Molócue in Zambézia province; Malema, Ribáuè and Erati in Nampula province; and Namuno and Chiúre in Cabo Delgado provincethis impact evaluation focuses on two districts in Zambézia province (Alto Molócue and Molumbo). In terms of value chains, the impact evaluation covers two high-potential value chains (soybean and pigeon pea), while the InovAgro project interventions focus on five value chains (maize, soybean, pigeon pea, sesame and groundnut).

The first section of the paper provides brief background information about the InovAgro projects and the impact evaluation research design, while the second section provides a brief description of the InovAgro project's theory of change, including relevant indicators to monitor project progress. Section 2 also describes the InovAgro project market development approach within the following intervention arms: seed market strategy, mechanization strategy, extension strategy and agricultural output trading market strategy for soybean and pigeon pea.

The third section of the paper outlines the data and empirical strategy employed to assess the InovAgro project's impact on short-term and long-term outcome variables at the household level. The study area is comprised of four treatment communities and four control communities in each of the two sampled districts, totaling eight treatment and eight control communities. Treatment communities include Benesse, Macolocotxo, Mugoliua, and Nandie in Molumbo, and Mohiua, Namilepe, Carmano and Caperula in Alto Molócue, while the control communities are Bediua, Corromana-Sede, Impidula-Sede and Mucoco in Molumbo, and Murico, Napalaca, Lugela and Inrule in Alto Molócue. A total of 1,749 households were interviewed in both rounds of the surveys: 889 households in the treatment communities (405 in Molumbo and 484 in Alto Molócue) and 860 in the control communities (410 in Molumbo and 450 in Alto Molócue). We employed the difference-in-differences (DID) and propensity score matching (PSM) approaches to assess the impact of the InovAgro project.

Section 4 summarizes preliminary findings, while Section 5 presents concluding remarks. We find that exposure to the InovAgro project increased the proportion of households selling soybean and pigeon pea by about $5 \%$ and $16 \%$, respectively. Exposure to the InovAgro project also resulted in higher shares of smallholder farmers using improved seed for soybean and pigeon pea (an increase of $6 \%$ for soybean and $2 \%$ for pigeon pea). We find that the InovAgro project is associated with significant increases in access to agricultural output market information from formal sources $(5 \%)$ and hired labor for farming activities (8\%). Despite the significant impacts on short term outcome variables, exposure to the InovAgro project has limited impact on long term outcome variables. This finding is not surprising given the impact evaluation covers only two years -- a short period of time to bring about the long-term impacts expected to eventually emanate from a Market System Development (MSD) project. 


\section{INTRODUCTION}

The Innovation for Agribusiness (InovAgro) project - funded by the Swiss Agency for Development and Cooperation (SDC) and implemented by Development Alternatives Initiatives (DAI) in partnership with COWI ${ }^{1}$ - operates in 11 districts, namely Mocuba, Ile, Namarroi, Molumbo, Gurúe and Alto Molócue in Zambézia province; Malema, Ribáuè and Erati in Nampula province; and Namuno and Chiúre in Cabo Delgado province. The overall objective of the InovAgro project is to increase incomes - and ultimately reduce poverty - of men and women small-scale farmers in northern Mozambique, through improved agricultural productivity and participation in selected high-potential value chains. These include maize, soybean, pigeon pea, sesame and groundnut. The InovAgro project's primary approach for achieving impact is to promote the development of inclusive and sustainable market systems such that the impact of the InovAgro project interventions is felt long beyond the termination of the project. This approach is also known as the Market System Development (MSD) approach (Osorio-Cortes and Lundy, 2018).

The InovAgro project is now in Phase III, which spans the years from 2018 to 2020. The InovAgro II project covered the three years prior, from 2014 through 2017, and the InovAgro I project took place from 2010 to 2013. The InovAgro I project focused on engaging lead firms and supporting model small businesses or small farmer entrepreneurs, such as input suppliers, large-scale agricultural output buyers and influential community lead farmers. These are put in place along with well-functioning market mechanisms to strengthen smallholder farmers' access to input and output markets. The InovAgro II project emphasized and pursued the strengthening and scaling up of the interventions begun in Phase I. It did so by means of farmer field days, promotions of lead-farmer demonstration plots, and greater extension efforts by enabling local traders of improved and certified seed varieties to provide extension, and by more targeting communities with growing demand for improved and certified seeds. Like the InovAgro II project, the InovAgro III project builds on previous phases by strengthening the capacity of seed companies and input suppliers.

The Swiss Development Corporation (SDC) engaged the International Food Policy Research Institute (IFPRI) to conduct an impact evaluation of selected aspects of the InovAgro II project, in order to identify and test which interventions of the MSD approach were most successful, and in what respects and how the interventions could be improved. This is what the current paper sets out to do. As part of the impact evaluation, a baseline survey with a sample of 1,886 households was conducted between August and September 2015, followed by a midline survey conducted between October and December 2017 during which the households interviewed in 2015 were re-interviewed. Although the InovAgro II project aimed to cover seven districts in northern Mozambique (Namuno and Chiúre in Cabo Delgado province; Erati, Mecaburi and Malema in Nampula province; and Alto Molócue and Molumbo in Zambézia province), only two districts (Alto Molócue and Molumbo) were selected for impact evaluation. This is because Alto Molócue and Molumbo were districts where the InovAgro I project did not have interventions, which would enable a clearer identification of InovAgro II's impact. The InovAgro I project covered four districts, namely Gurúe and Mocuba in Zambézia province and Erati and Chiúre in Cabo Delgado province.

In each district selected for the impact evaluation, eight communities (four treatment or beneficiary communities and four control or non-beneficiary communities) were randomly selected for impact evaluation. Though the InovAgro II project included value chains in soybean, pigeon pea, seed and other agricultural inputs, as well as oilseed, groundnut and sesame crops, this impact evaluation focuses on beneficiary and non-beneficiary households' involvement in the soybean and pigeon pea value chains. Preliminary results from the impact evaluation show that exposure to the InovAgro II project interventions had positive impact on short term outcome variables (such as usage of improved seed) but limited impact on long term outcome variables. This is expected given that the impact evaluation takes place two years following the begin of interventions, which is a short duration of time for market system development level impacts to emerge.

\footnotetext{
${ }^{1}$ COWI originally operated under the name Chr. Ostenfeld \& W. Jønson, from which the company’s current acronym was derived.
} 
This paper is structured in five sections, including this introductory section. The second section briefly describes the InovAgro project's theory of change, including the corresponding outcome indicators, and provides background information on the InovAgro project's intervention strategies. Section 3 is devoted to outlining the impact evaluation research design and the data and empirical strategy employed in the impact evaluation. Preliminary findings on the potential impacts of the InovAgro project are presented in the fourth section, and the final section presents concluding remarks. 


\section{INOVAGRO MARKET DEVELOPMENT APPROACH}

\section{Overview and Theory of Change}

The InovAgro project mapped the multifold ways the project's impact would be manifested, and how it would directly and indirectly benefit actors across the various layers of the value chain. Project documents also considered how it may be possible to establish plausible attribution in changes in the market system to InovAgro project activities and thus draw causal linkages to the benefits accrued to the smallholder farmers (InovAgro 2014). At project inception, project reports anticipated that InovAgro would lead to observed changes in agricultural input use, agricultural production, output sales, access to market services and information, and land property rights (Erman, Ghebru and Mogues, 2016).

The InovAgro project has a carefully articulated theory of change, illustrated in Figure 2.1. This figure demonstrates how the interventions undertaken under InovAgro-expressed as operating at the "activity level" - would ultimately result in greater impacts such as increased farmer income and reduced food insecurity and poverty. The pathway from activities to impact includes, for example, strengthened linkages between farmers and agricultural output buyers - at the "output level"-and increased participation by smallholder farmers in high-potential value chains - at the "outcome level". The exercise of conducting an impact evaluation seeks to trace this theory of change by judicious identification of variables to be measured and analyzed. Doing so contributes not only to identifying the impact of the InovAgro project activities, but also to shedding empirical light on the mechanisms through which such impact occurs.

Figure 2.1. Theory of change of the InovAgro project

\begin{tabular}{|c|c|c|c|}
\hline 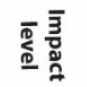 & \multicolumn{3}{|c|}{$\begin{array}{l}\text { Increased income and improved economic security for poor men and women small-scale farmers } \\
\text { in Northern Mozambique through agricultural productivity and } \\
\text { commercial business services }\end{array}$} \\
\hline 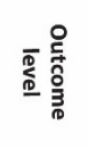 & $\begin{array}{l}\text { Increased farmers } \\
\text { participation in commercial } \\
\text { value chains }\end{array}$ & $\begin{array}{l}\text { Increased private sector } \\
\text { companies transacting } \\
\text { directly with the farmers }\end{array}$ & $\begin{array}{l}\text { Increased commercial } \\
\text { transactions, market oriented } \\
\text { relationships and effective } \\
\text { supply coordination in the } \\
\text { seed industry }\end{array}$ \\
\hline 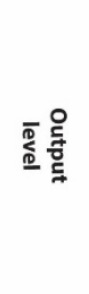 & $\begin{array}{l}\text { 1. Farmers have more equitable } \\
\text { relationships with private } \\
\text { sector companies; } \\
\text { 2. Farmers adopt improved } \\
\text { commercial farming practices; } \\
\text { 3. Farmers have economic and } \\
\text { social security. }\end{array}$ & $\begin{array}{l}\text { 1. Farmers are linked to output } \\
\text { buyers; } \\
\text { 2. Farmers have access to } \\
\text { affordable and customized } \\
\text { credit and finance packages; } \\
\text { 3. Farmers have functional } \\
\text { linkages with input suppliers } \\
\text { and service providers } \\
\text { (includes mechanization and } \\
\text { extension) }\end{array}$ & $\begin{array}{l}\text { 1. Farmers have increased } \\
\text { demand for certified seed; } \\
\text { 2. Private sector has increased } \\
\text { direct seed sales and } \\
\text { technical services to farmers; } \\
\text { 3. Collaboration in the seed } \\
\text { sector is enhanced due to } \\
\text { the establishment of a } \\
\text { national dialogue platform. }\end{array}$ \\
\hline 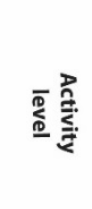 & $\begin{array}{l}\text { 1. Farmers organization \& } \\
\text { empowerment activities; } \\
\text { 2. Farmers capacity building } \\
\text { activities; } \\
\text { 3. Gender main streaming } \\
\text { activities; } \\
\text { 4. Land tenure security activities }\end{array}$ & $\begin{array}{l}\text { 1. Input, services and output } \\
\text { market linkages activities; } \\
\text { 2. Private sector capacity } \\
\text { building activities; }\end{array}$ & $\begin{array}{l}\text { 1. Seed multiplication activities; } \\
\text { 2. Seed and input } \\
\text { demonstration activities; } \\
\text { 3. Seed dialogue platform } \\
\text { activities; }\end{array}$ \\
\hline urce & & & \\
\hline
\end{tabular}

Key indicators expected by the project by the end of InovAgro II include increases in soybean, pigeon pea, groundnut and sesame annual net profit per hectare of production, by $43 \%, 234 \%, 139 \%$ and $147 \%$, respectively, compared to 2012/2013 baseline levels. These projections assumed that prices would be stable, which they have not been, and that climatic conditions would remain favorable for crop 
production. As we discuss later, irregular rainfalls have caused serious adverse effects over the course of the project's implementation. Nevertheless, three major outcomes of the project were outlined in the original plan, by which the overarching goal of the project would be met.

The first expected outcome of the project was to increase smallholder participation in commercial value chains and smallholder competitiveness. The three expected indicators of progress toward the first outcome include (i) smallholder farmers' increased productivity for their production of soybean, pigeon pea, sesame and groundnut, (ii) increased numbers of smallholder farmers participating in commercial value chains through increased access to quality agricultural inputs and improved commercial value chain knowledge, and (iii) increased total volume of production for smallholder farmers supported by the InovAgro project, for each value chain crop. The project's extension intervention strategy and organized field days have been the primary vehicles for achieving the objective of improving farmers' production capacity. The InovAgro project has sought to use field days and increased numbers of visits to smallholder farmers by extension officers to help raise demand for quality seed and other yield-enhancing agricultural inputs, as well as to support the promotion of good agricultural practices in general, such as planting in a timely manner, weeding, etc. The project's interventions to facilitate the acquisition of land titles, national identification cards, and tax registrations of smallholder farmers are the primary vehicles by which the objective of increasing smallholder farmers' economic and social security has been sought. And the InovAgro project has primarily attempted to increase smallholder farmers' access to interconnected services such as finance and mechanization by (i) facilitating the relationships of financial institutions to smallholder farmers and the former's willingness to offer loans, (ii) establishing savings groups among smallholders to enable group purchases of certified seed and other agricultural inputs, and (iii) promoting the relationship between smallholder farmers and mechanization service providers to improve agricultural production and productivity.

The second expected outcome of the InovAgro project is to increase direct transactions between private sector companies and smallholder farmers. The two expected indicators of progress toward this outcome include (i) the increased number of private sector companies establishing commercial contracts with smallholder farmers to purchase their agricultural production, and (ii) an increased number of private sector companies selling agricultural inputs to smallholder farmers. The project's output trading market strategy to increase the number of agricultural output buyers, the total volume and total financial value of agricultural output purchased, as well as the project's seed market strategy to increase the number of companies selling inputs directly to smallholder farmers, have been the primary vehicles for achieving the objective to create market linkages between agricultural output buyers and input suppliers on the one hand, and smallholder farmers on the other hand. To achieve the objective of increasing the number of financial institutions lending to smallholder farmers, again, the InovAgro project has facilitated relationships of financial institutions to offer loans to smallholder farmers.

The third expected outcome of the InovAgro project is to increase commercial transactions, market-oriented relationships and effective supply coordination in the seed industry. The two expected indicators of progress toward this outcome are (i) a reduced volume of pigeon pea and soybean certified seed supplied to smallholder farmers by the government and donor funded projects, and (ii) an increase in the number of formal agreements between agricultural research institutions and private sector seed companies to directly supply basic and pre-basic seed (seed for multiplication into certified seed) to private sector seed companies. The project's seed market strategy has been the primary vehicle to achieve the objective of increasing the effective demand for certified seed by smallholder farmers, measured both in terms of the number of smallholder farmers purchasing improved and certified seeds and the volume of seed purchased directly by smallholder farmers. The InovAgro project's interventions to support the opening of new seed stores by private sector seed companies has been the primary way the project has sought to achieve the objective of increasing direct seed sales and increased technical services offered by the private sector to smallholder farmers. And the InovAgro project has primarily sought a better enabling environment and services for certified seed production and sales. It did so firstly by means of approving the operational plan produced for the national seed dialogue platform (NSDP) and thus contributing to the development of the seed sector in Mozambique, as the NSDP agrees upon decisions to recommend for government action to enable the seed sector to be more competitive. Secondly, it sought to do so by 
supporting Mozambique's National Directorate of Agrarian Services (DNSA) of the Ministry of Agriculture and Food Security (MASA) to create and manage a web-based tool for disseminating information to the private sector stakeholders, as well as by supporting an accreditation program through which DNSA trains and licenses private sector seed inspectors to monitor the quality of seed produced by the private sector seed companies.

\section{Seed Market Strategy}

InovAgro's seed market strategy is two pronged. The first goal is to establish a commercial distribution network, by facilitating market access for a growing number of private sector seed suppliers including PANNAR, Phoenix Seeds, Sementes Nzara ya Pera, Oruwera, JNB, IKURU and Klein Karoo. In addition to the seed suppliers, InovAgro trains dozens of agro-dealers to work with the seed suppliers to retail the certified product to local smallholder farmers in the project implementation areas. The growth in the number of private sector seed suppliers entering the market in these areas is intended to contribute to a crowding-in effect, more competitive pricing, and the ability of the seed companies to thrive and expand their operations.

The second and parallel goal of the seed market strategy is to generate demand and promote the use of improved and certified seed. To this end, InovAgro partners (seed companies) install demonstration plots and organize field days targeted at smallholder farmers, where crop performance at the various stages of planting and harvest is demonstrated, extension messages on good agricultural practices are promoted and outlets are advertised where improved and certified seed can be purchased. During a given agricultural season, three field days are usually realized: one at planting season, another at weeding season and the last one at harvesting time. Technicians from seed companies work to create demand by smallholder farmers for improved and certified seeds by introducing, marketing and promoting an assortment of seed products and developing a commercial seed distribution network such that smallholder farmers have better access to improved and certified seeds.

Demonstration plots are established on lead farmers' own fields. Selected by seed companies promoting their certified seeds, lead farmers are usually farmers who have great credibility and social capital established with other farmers in their communities, and have some experience using improved seed before becoming lead farmers. Many of the lead farmers who have demonstration plots on their fields are also village-based agents (VBAs) of agro-dealers. VBAs usually do not have their own shops, but sell certified seed and other agricultural inputs generally acquired from local agro-dealers (input suppliers) within their communities. Due mainly to lack of own shops, VBAs are faced with financial constraints to afford large scale of seeds and limited storage capacities, resulting in higher risk of seed damage during storage. Other approaches to promoting demand include mobile agro-dealers and seed fairs, where efficiency gains can be made by bringing various entities (seed companies, agro-dealers and output buyers) together to sell agricultural inputs to and buy agricultural outputs from smallholder farmers. Seed fairs are generally organized around the beginning of the agricultural season.

Data from the baseline and midline surveys show that the share of smallholder farmers that visited demonstration plots increased from $0.7 \%$ in 2015 to $14.6 \%$ in 2017 in control communities and from $0.5 \%$ in 2015 to $23.3 \%$ in 2017 in treatment communities. The difference in the share of smallholder farmers that visited demonstration plots between the treatment and control communities is statistically significant in 2017 but not in 2015, suggesting that the InovAgro II project led to higher exposure to demonstration plots over time. Similar findings are found for the proportion of smallholder farmers that attended field days in demonstration plots.

\section{Mechanization Strategy}

The idea behind the mechanization intervention is to engage farmers who own their own tractors or other large machines such as threshers, etc., and see if they would consider offering paid services using their equipment to other smallholder farmers who cannot afford purchasing their own equipment. Like InovAgro's seed market strategy, the mechanization strategy also follows a two-pronged approach. One 
prong is the provision of mechanization services. This consists of identifying tractor owners as potential mechanization service providers and providing them with technical training on how to effectively and efficiently operate their tractors, planters, threshers and/or shellers. The approach also involves training on how to give effective sales pitches to other farmers in their communities, outlining the reasons these neighbors would benefit from the supplied mechanization services. The University of Zambeze, known as UniZambeze, has been engaged in offering full day trainings to over a dozen mechanization service providers located in the districts of Gurué, Mocuba and Malema (districts different from those selected for impact evaluation). The government's Fundo Desenvolvimento Agrario (FDA) is also funding mechanization parks to service smallholder farmers in some of the InovAgro project districts, (these too are not part of the study area). Recipients of the mechanization tractor parks receive the parks on credit and have to pay them off over a ten-year period. This is to bring tractor use to areas where there has been no tractor use in the past.

Unfortunately, the mechanization efforts in the district of Alto Molócue-one of the districts selected for the impact evaluation - have not been very successful. A service provider, Damião Caixão, had his equipment confiscated by the bank due to loan default. Arrangements were still in the works as of June 2017 to see whether a second mechanization service provider, ECOPS Limitada would have success in the area in the 2017-2018 agricultural season. In Molumbo, the primary tractor owner that InovAgro worked with to provide mechanization services decided that he was no longer interested to provide mechanization services to other farmers in his community. This has been another challenge in the project locations of the InovAgro evaluation.

The other prong of the mechanization intervention strategy is directly on the demand creation front. During the same field days in which improved and certified seed purchases were promoted by extension workers, mechanization services are also demonstrated, and farmers' questions answered. Given that the costs of using a tractor or other mechanization services are perceived as quite high, take-up of these services has been relatively slower than that of the improved and certified seeds.

\section{Extension Intervention Strategy}

InovAgro primarily partners with the District Services for Economic Activities (SDAE) - the local governmental district offices for agriculture and other economic sectors - to provide greater extension service delivery to smallholder farmers. However, InovAgro also partnered with seed companies (such as PANNAR, Phoenix Seeds, Sementes Nzara Yapera, Sygenta and AKA) in Alto Molócue, Gurue, Ile and Mocuba to deliver extension services as either a substitute for or a complement to SDAE provision. According to InovAgro (2016), between October 2015 and May of 2016, extension officers working under InovAgro project's umbrella visited 5,260 smallholder farmers to assist them with extension advisory services aimed, among other things, at driving up smallholder farmers' demand for improved and certified seeds.

Data from the baseline and midline surveys show that extension service coverage jumped from $1.4 \%$ in 2015 to $12.0 \%$ in 2017 in the control communities and from $2.1 \%$ in 2015 to $24.2 \%$ in 2017 in the treatment communities. The percentages of smallholder farmers that received extension services are statistically different between the control and treatment communities in 2017 but not in 2015. This suggests that exposure to the InovAgro project resulted in higher coverage of extension services over time. Overall in both Alto Molócue and Molumbo, the share of smallholder farmers that received extension services increased from $1.7 \%$ in 2015 to $18.2 \%$ in 2017, with a higher share in Alto Molócue in 2015 (3.2\% versus 0.1\% in Molumbo) but a higher share in Molumbo in 2017 (11.6\% versus 25.9\% in Alto Molócue). We point out that extension service coverage found in 2017 is considerably higher than the average share found in Mozambique (4.3\%), and in Zambézia province (1.9\%), using data from the latest nationally representative Agricultural Household Survey (IAI) 2015 conducted by the Ministry of Agriculture and Food Security (MASA). 


\section{Output Trading Market Strategy: Soybean and Pigeon Pea}

The InovAgro project supports improved access to output marketing for five crops, namely maize, pigeon pea, soybean, sesame and groundnut. This is done by negotiating deals with potential output buyers prior to when output purchases are generally made. The names of some of the output buyers that the project has engaged for negotiation include Cargill, IKURU, and WINUA for soybean and maize, and Mubula Commercial and HAMID Commercial for pigeon pea (InovAgro 2016) for the purposes of export, use in poultry feed, or resale to other local companies.

The output sellers identified by the InovAgro project have not generally been smallholder farmers, but rather community aggregators who need to be partially subsidized by the InovAgro project (up to $50 \%$ of their income) to increase the number of buying points and facilitate purchases of product from the surrounding local farmers (Nephas Munyeche, DAI, personal communication, June 6, 2017). Field visits realized in 2019 in Alto Molócue revealed that farmers associations also aggregate agricultural output from the surrounding smallholder farmers, who are members or nonmembers of the given association, to then sell to agricultural output buyers, taking advantage of economies of scale and the price premium given by agricultural buyers when buying from farmers associations rather than individual smallholder farmers. Community aggregators and other medium-to-large scale agricultural output buyers usually have several buying posts - generally staffed by an employee — where a log of selling records are kept, and these records have helped inform InovAgro's strategic efforts to improve output purchase deals over time.

Political instability and violence in 2015 to 2016, which led many Mozambicans to flee across the border to Malawi, dampened and negatively affected the development of commercial agricultural activities in northern Mozambique. Molumbo, located closer to the Malawi border, appeared to have been more affected by the political instability than Alto Molócue. Higher insecurity when travelling by road coupled with unreliable road access as a result of the political instability discouraged trade between villages, districts and provinces, including transport of agricultural inputs such as improved and certified seeds, fertilizers and pesticides. The InovAgro project is working to strengthen the trust between farmers associations and agricultural output buyers such that the risks and transaction costs faced by agricultural output buyers when purchasing agricultural outputs from smallholder farmers at various buying posts can be somewhat ameliorated (InovAgro, 2016).

In addition to the political instability experienced during the 2015/2016 agricultural season, Zambézia province experienced irregular rains during this same period, which negatively affected agricultural production and productivity in both districts covered by the InovAgro impact evaluation. However, According to InovAgro (2016), the delayed rains improved performance for pigeon pea while negatively interfering in the performance of soybean and maize production, especially reducing threshing efficiency and increasing post-harvest losses due to higher humidity during and after harvesting season.

Another challenge faced by the InovAgro project when promoting the purchase of agricultural output from smallholder farmers concerned the manual meters used by agricultural output buyers, which are not capable of measuring moisture levels when purchasing agricultural outputs. Providing digital scales, brand and price posters and record keeping training to agricultural output buyers is another area where the InovAgro project is intervening to promote agricultural output purchases from smallholder farmers. Furthermore, the InovAgro project seeks to help community aggregators to properly package their agricultural output as per the company brand and thus achieve traceability such that the end-buyer can trace the source of the crop and wholesale buyer. The project subsidizes better storage equipment and training on the principles of warehouse management as well as the purchase of mobile phones and airtime for agricultural output buyers staffing their buying posts. And the project also facilitates access to development projects that can help subsidize physical fixed infrastructure, like buildings (Nephas Munyeche, personal communication, June 6, 2017).

Finally, in addition to the above strategies, the InovAgro project also added an access-to-finance "economic security strategy" to enable farmers to achieve access to the financial resources needed for inputs and services procurement. This strategy has involved commercial bank linkages and savings groups. 
Data from the baseline and midline surveys demonstrated that the proportion of smallholder farmers that grew soybean (pigeon pea) increased from 1.8\% (62.7\%) in 2015 to $19.0 \%(83.1 \%)$ in 2017 in control communities and from 3.4\% (70.4\%) in 2015 to $24.7 \%(80.0 \%)$ in 2017 in treatment communities. These differences between treatment and control communities in terms of shares of smallholder farmers that grew soybean and pigeon pea are statistically different in both years. This suggests that exposure to the InovAgro project resulted in a higher proportion of smallholder farmers that grew soybean and pigeon pea in both districts over time. The proportion of smallholder farmers that grew soybean is consistently and statistically higher in Molumbo than in Alto Molócue in both years (3.6\% versus $1.6 \%$ in 2015 and $40.3 \%$ versus $6.1 \%$ in 2017). On the contrary, in the case of pigeon pea, the proportion of smallholder farmers producing the crop was significantly and statistically higher in Alto Molócue than in Molumbo (83.9\% versus 47.2\% in 2015 and $83.7 \%$ versus $79.0 \%$ in 2017).

With regard to sales, data from baseline and midline surveys illustrate that the share of smallholder farmers that sold soybean were comparable in the control and treatment communities in 2015 $(1.1 \%$ versus $1.3 \%)$, but the share was significantly and statistically higher in treatment than in the control communities in 2017 (8.9\% versus 14.2\%). On the other hand, the proportion of smallholder farmers that sold pigeon pea was statistically higher in the control communities $(38.4 \%)$ than in the treatment communities (31.2\%) in 2015; however, the situation reversed in 2017 when the share was statistically higher in the treatment communities $(33.1 \%)$ than in the control communities $(25.4 \%)$. This could be an indication that the InovAgro project led to an increased share of smallholder farmers that sold soybean and pigeon pea over time. 


\section{DATA AND METHODOLOGY}

\section{Impact Evaluation Research Design}

The objective of this impact evaluation is to assess the linkages between the market system development (MSD) approach operationalized by InovAgro and its impacts on household welfare of participating farmers, using a technically rigorous impact evaluation methodology of evaluating a development intervention that uses the MSD approach in the agricultural sector.

We employ a quantitative approach of data collection and analysis. According to White 2011, multiple quantitative methods allow comparing and testing the sensitivity of results of one approach against the other. Our initial design was based on the intent to carry out a randomized controlled trial (RCT) alongside other panel and cross-sectional based approaches as explained below. RCTs are considered the 'gold standard' for addressing the type of question that is at the heart of this study: What difference did the intervention make to the development outcomes considered, and how large is the difference that it made? More generally, carefully designed and executed experimental and quasiexperimental studies - which are a subset of quantitative approaches - are crucial in order to credibly attribute changes in outcomes to an intervention or project. The essential approach of RCTs in the context of InovAgro consisted in working with the implementing agency to first identify communities within the study area that would be eligible to participate in the project, based on the project's own criteria. Then, from this set of eligible communities, the study team randomly selected communities to be the focus areas for project implementation, with the other communities remaining non-participant areas. Within communities, a similar selection took place at the farmer level.

A baseline survey was undertaken in 2015 among both participating and non-participating farmers, and the midline survey was conducted in 2017 on the same sample as the baseline survey. A total of 1,886 households were interviewed in 2015 covering the agricultural season 2014/2015 and of 1,749 households were re-interviewed in 2017 covering the agricultural season 2016/2017. Details of the sampling techniques and the data collection method are outlined in the section titled "Data and Sample Selection" below. Both mean differences and regression analysis are conducted with the survey data to determine the impact of InovAgro II project. Section 4 presents the preliminary results.

Randomization solves the problem of selection bias because InovAgro and non-InovAgro areas were drawn randomly from the same underlying population and therefore, the average characteristics of these groups will not systematically vary, and any differences observed in the outcomes of interest can therefore be attributed to the InovAgro intervention. The core experimental study design, mentioned above and elaborated in the data and sample selection section below, can be classified as a 'goldstandard' strategy to assess the impact of the InovAgro intervention. It therefore yields reliable results. Given that, after extensive discussions with the implementing agency shortly before the 2015 baseline survey, it was concluded that the RCT approach was not feasible from an operational perspective (see also Erman et al. 2015), we employ selected methods from the body of quasi-experimental approaches mainly, to account for any potential discrepancies in observable and unobservable characteristics between treatment and control groups, each of which addresses selection bias in different ways and has different strengths and limitations, with none being unambiguously superior in all circumstances (Ravallion 2007).

One of the possible limitations, even in 'gold-standard' randomized designs, is that the units selected for treatment may in fact not receive the treatment, or may not receive it in the fashion that was intended by the intervention. Conducting standard analysis that does not account for this potential discrepancy between treatment and intention to treat could understate the impact of the intervention. In the case of the InovAgro II project, we conducted careful discussions with the implementing agency about the importance in adhering to a pre-determined design. Even with these measures in place, however, it is impossible to completely rule out any potential discrepancies between design and actual treatment, because in some cases it is hard to obtain full field information about the actual features of treatment. Therefore, this impact evaluation supplements the core analysis with analysis that uses the intention-totreat data as an instrument for treatment (Abadie et al. 2002). 
A second approach from the quasi-experimental toolbox that we employ on our data from the experimental design is double-differencing. Randomization fundamentally avoids the existence of systematic differences between the treated and non-treated elements. However it does not prevent nontrivial differences that may be present by chance. Therefore, we conduct a difference-in-differences analysis, rather than derive results only on the basis of the endline surveys and rather than limiting the use of the baseline survey for the purposes of stratification (White 2013). The double-difference analysis compares the change in outcomes before and after the InovAgro interventions for farmers located in areas that benefited from the intervention and farmers without intervention. The double-difference method also helps account for any pre-treatment differences among beneficiary and non-beneficiary households. The baseline and the midline waves of survey data are used to implement this analysis.

The double-difference analytical tool is a quantitative method often used to estimate and compare change in outcome pre and post program for participant and non-participant (Angrist and Pischke, 2008). The advantage of using the double difference method is that it nets out the effects of additive factors that have fixed (time-invariant) impacts on outcome indicators, or that reflect common trends affecting participants and non-participants equally such as changes in prices (Ravallion, 2007).

Finally, we use statistical analysis to account for other important, although less critical limitations of the experimental approach. One such issue we immediately think of is spillover effects, whereby untreated areas may also profit from the intervention. The existence of spillovers would lead to an underestimation of the treatment effect. The use of communities as the level at which randomization takes place, rather than solely randomizing only at the farmer level (see detailed discussion of this design in the empirical results section) is a critical step in accounting for spillover effects. However, to even further test the robustness of our results to spillover. In the same vein, we include a host of other controls to rule out alternative explanations of the effects we identify.

\section{Data and Sample Selection}

The treatment unit of this evaluation is the community (comunidade) level. Communities are administrative units within localities (localidades), which in turn are administrative units inside administrative posts (posto administrativos) - the largest units on a district level. Initially the International Food Policy Research Institute (IFPRI), SDC, and the implementing agency Development Alternatives Inc. (DAI) agreed that a randomized controlled trial (or experimental) approach would be used in the impact evaluation, and the research proposal was designed based on this approach. Shortly before conducting the baseline survey, however, it was determined that the experimental design, in which the treatment and control areas are selected randomly, was not feasible due to limitations faced by DAI.

Instead, the implementing agency selected four communities in each district where InovAgro's intervention would be carried out. All selected treatment communities were located in the same administrative post within each district. The control communities were selected from comparable ${ }^{2}$ localities in a different administrative post from where the treatment communities are located. We chose a different administrative post for the control communities to limit spillovers effects. The household listing exercise in both treatment and control areas secured information about the households regarding age and gender of household head and their soybean and/or pigeon pea production. This listing information was used to select the final set of control communities based on the extent of soybean and/or pigeon pea cultivation. The final sample is drawn from 16 communities in four administrative posts in two districts. The communities are listed in Table 3.1.

\footnotetext{
${ }^{2}$ As defined by the implementing agency.
} 
Table 3.1. Study area and sample size

\begin{tabular}{|c|c|c|c|c|c|c|}
\hline \multirow[b]{2}{*}{ District } & \multirow[b]{2}{*}{ Administrative post } & \multirow[b]{2}{*}{ Community } & \multicolumn{2}{|c|}{2015} & \multicolumn{2}{|c|}{2017} \\
\hline & & & $\mathbf{N}$ & $\%$ & $\mathbf{N}$ & $\%$ \\
\hline \multirow{8}{*}{ Molumbo } & \multirow{4}{*}{$\begin{array}{l}\text { Treatment } \\
\text { Molumbo-Sede }\end{array}$} & Benesse & 117 & 6.2 & 114 & 6.5 \\
\hline & & Macolocotxo & 100 & 5.3 & 89 & 5.1 \\
\hline & & Mugoliua & 120 & 6.4 & 105 & 6.0 \\
\hline & & Nandie & 108 & 5.7 & 97 & 5.6 \\
\hline & \multirow{4}{*}{$\begin{array}{l}\text { Control } \\
\text { Corromana-Sede }\end{array}$} & Bediua & 96 & 5.1 & 78 & 4.5 \\
\hline & & Corromana-Sede & 119 & 6.3 & 107 & 6.1 \\
\hline & & Impindula-Sede & 121 & 6.4 & 109 & 6.2 \\
\hline & & Mucoco & 125 & 6.6 & 116 & 6.6 \\
\hline \multirow{8}{*}{ Alto Molócue } & \multirow{4}{*}{$\begin{array}{l}\text { Treatment } \\
\text { Nauela }\end{array}$} & Mohiua & 124 & 6.6 & 123 & 7.0 \\
\hline & & Namilepe & 120 & 6.4 & 114 & 6.5 \\
\hline & & Carmano & 123 & 6.5 & 123 & 7.0 \\
\hline & & Caperula & 125 & 6.6 & 124 & 7.1 \\
\hline & \multirow{4}{*}{$\begin{array}{l}\text { Control } \\
\text { Alto-Molócue Sede }\end{array}$} & Murico & 119 & 6.3 & 116 & 6.6 \\
\hline & & Napalaca & 122 & 6.5 & 108 & 6.2 \\
\hline & & Lugela & 125 & 6.6 & 124 & 7.1 \\
\hline & & Inrule & 122 & 6.5 & 102 & 5.8 \\
\hline Total & & & 1,886 & 100 & 1,749 & 100 \\
\hline
\end{tabular}

Source: Authors' computation using InovAgro II baseline (2015) and midline (2017) data sets (see also Smart et al. 2019).

Power calculations during the planning stage of this project-which were based on the more demanding methodology of a randomized controlled trial, rather than the quasi-experimental approach ultimately pursued - indicated that about 2,000 households were needed, which is the approximate number generated when adjusting for design effect and attrition rate. As evidenced from the total number in Table 3.1, a total of 1,886 (933 from the treatment communities and 949 from the control communities) were interviewed during the baseline. Of which, a total of 1,749 households ( 889 from the treatment communities and 860 from the control communities) were again interviewed during the midline. This lower number of re-interviewed households during the midline survey is due to attrition. The attrition rate varied across districts, ranging from 5\% in Molumbo to $10 \%$ in Alto Molócue, with an overall attrition rate of $7 \%$.

For both the baseline and midline surveys, enumerators used Computer-Assisted Personal Interviewing (CAPI) to collect the data, and the survey instrument was designed using the Census and Survey Processing System (CSPRO). Enumerators took an average of 45 minutes to administer the survey. The field team consisted of 12 enumerators for the baseline survey and 16 enumerators for the midline survey. For both the baseline and midline surveys, the field teams were supervised by two team leaders and managed by two field coordinators. Listing and data collection took place between August and September 2015 for the baseline survey and between October and December 2017 for the midline survey, with both surveys implemented by IFPRI.

\section{Empirical Method}

We employed difference-in-difference (DID) estimation to assess the impact of the exposure to InovAgro II project on indicator outcomes. To do so, we estimate the following regression model:

$$
Y_{i j t}=\beta_{0}+\beta_{1} C_{j}+\beta_{2} T_{t}+\gamma I_{j} \times T_{t}+\varepsilon_{i j t}
$$

Where $Y_{i j t}$ denotes outcome variable of interest for household $i$ in community $j$ at time $t ; C_{j}$ is an indicator variable equal to one if community $j$ was exposed to InovAgro II project (treatment 
community) and zero otherwise (control community); $T_{t}$ is a dummy variable equal to one if year equal to 2017 (midline survey year) and zero if year equal to 2015 (baseline survey year); $I$ is the set of independent variables; $\varepsilon_{i j t} \varepsilon_{i j t}$ is a random error with mean zero and constant variance; and $\beta_{0}, \beta_{1}, \beta_{2}$ and $\gamma$ are unknown parameters to be estimated. The key parameter of interest is $\gamma$ which gives the average impact of the exposure to InovAgro II project on a given outcome variable: the average difference between treatment and control groups after accounting for differences in trends between the two groups. One of the key assumptions behind the DID approach is that other covariates - rather than InovAgro II project — do not change between the baseline and midline surveys. However, this assumption is violated in our case. We controlled for household-level characteristics that could affect the difference in trends between treatment and control groups by modifying the above regress as follows:

$$
Y_{i j t}=\beta_{0}+\beta_{1} C_{j}+\beta_{2} T_{t}+\boldsymbol{\beta} \mathbf{X}_{i j t}+\gamma I_{j} \times T_{t}+\varepsilon_{i j t}
$$

Where $\mathbf{X}_{i j t}$ represents a set of household-level characteristics that could influence outcome variables of interest.

We are also interested in estimating the average effect of InovAgro II project exposure on households who were exposed to InovAgro II project (also known as average treatment effect on the treated referred to as ATT). Putting differently, we are interested in assessing whether InovAgro II project are generating the intended effects among beneficiaries (assessing the mechanisms by which beneficiaries are responding to the InovAgro II intervention). ATT is given by the difference between the average outcome variable in the presence of the InovAgro II project and the average outcome variable had the InovAgro II project not been implemented, among households who benefited from InovAgro II project. This raises a challenge because we cannot observe the average outcome variable for households who benefited from InovAgro II project had those households not been InovAgro II beneficiaries (absence of data on counterfactual outcome variable). If we attempt to estimate the average outcome variable among beneficiary households had they not benefited from InovAgro II project using households who were not exposed to InovAgro II project, we would be faced with a selection bias problem. This is because either some household covariates could influence households' decision to self-select into participation in InovAgro II project or InovAgro II project beneficiaries were purposively selected by project implementing agency. We estimate the following the regression model:

$$
Y_{i j t}=\alpha+\gamma C_{j}+\boldsymbol{\beta} \mathbf{X}_{i j t}+u_{i j t}
$$

This regression model suffers from the selection bias problem described above and we control for this selection bias using the propensity score matching (PSM) approach. PSM, which is the probability of assignment to InovAgro II project conditional on before-intervention characteristics, is specified as follows:

$$
p_{i}=p\left(X_{i j t}\right)=\operatorname{Pr}\left(C_{j}=1 \mid X_{i j t}\right)=E\left[C_{j}=1 \mid X_{i j t}\right]=F\left\{h\left(X_{i j t}\right)\right\}
$$

Where $F\{\cdot\}$ can be a normal or logistic cumulative distribution. PSM controls for selection bias by constructing a counterfactual for households who benefited from the InovAgro II project by matching every household from the treatment communities with those from the control communities with similar characteristics. Once the PSM is estimated, the ATT can be computed as follows:

$$
\begin{aligned}
A T T & =E\left\{Y_{i}^{T}-Y_{i}^{C} \mid C_{j}=1\right\}=E\left[E\left\{Y_{i}^{T}-Y_{i}^{C} \mid C_{j}=1, p_{i}\right\}\right] \\
& =E\left[E\left\{Y_{i}^{T} \mid C_{j}=1, p_{i}\right\}-E\left\{Y_{i}^{C} \mid C_{j}=0, p_{i}\right\} \mid C_{j}=1\right]
\end{aligned}
$$


where $Y_{i}^{T}$ and $Y_{i}^{C}$ denote, respectively, the outcome variable if household $i$ benefited (treatment communities) and did not benefit (control communities) from the InovAgro II project.

\section{Outcome variable definition}

We consider the effect of exposure to the InovAgro II project on two types of outcome variables: short term and long term. Short term outcome variables include "household sold produced crops in the most recent agricultural season (any crop, soybean and pigeon pea)", "household adopted improved seed (soybean and pigeon pea)", "household had access to output market information from formal sources", and "household hired labor for any farming activities". Each of these short-term outcome variables are dummy variables, equal to one if success and zero if failure. Total value of production for soybean, pigeon pea and maize - obtained by multiplying production by median community-level price of each crop-is another short-term outcome variable we considered. Long-term outcome variables comprise of "household had temporary migrant head or spouse" (a dummy variable equal to one if success and zero if failure), "number of temporary migrants in the household", "household head or spouse engaged in nonfarm activity as either a primary or secondary activity" (dummy variable), and an "asset index" reflecting household wealth status. The number of temporary migrants in the households represent the number of household members aged 15 or older who were absent in the household in the last 12 months prior to the date the household were interviewed. The asset index is computed using principal component analysis (PCA), taking into account both animal and asset ownership. We considered four categories of asset index: i) functioning assets comprising of productive assets, ii) functioning and non-functioning assets consisting of productive and non-productive assets, iii) functioning durable assets consisting of productive durable assets, and iv) functioning durable and nondurable assets comprising of productive durable and nondurable assets. 


\section{DESCRIPTIVE RESULTS}

\section{Access to Input Market Information}

The percentage of households that received input market information (from any source) nearly doubled for both control and treatment households ( $35 \%$ to $59 \%$, table 4.1 ). The most common source of input market information is still from relatives/friends (up to $42 \%$ from $10 \%$, table 4.2 ). Other sources of input market information that became substantially more prevalent between 2015 and 2017 in both the control and the treatment groups included formal or informal authorities (e.g. village leaders, agricultural association leaders, NGOs, etc.), as well as extension agents, input sellers and output buyers. The percentage of households that received information from an authority rose from $8 \%$ to $24 \%$ on average across the two groups, and the percentage of households that received information from an extension agent rose from $15 \%$ to $23 \%$ on average, with this category of sourced information being more common in the treatment groups than in the control groups: $29 \%$ of treatment households received information via extension agents, input sellers or agricultural output buyers in 2017 , compared to $17 \%$ in the control group, whereas only $17 \%$ of those in the treatment group, and $13 \%$ of those in the control group had received information from one of these sources in 2015 . This certainly seems to speak to the increased activities by extension agents and village based agro-dealers associated with InovAgro's intervention in the intervening time period. The post-intervention proportion of households who accessed information from extension agents and value chain actors (input sellers or agricultural goods buyers) has shown a significant upward shift for beneficiary households as compared to non-beneficiary households.

Table 4.1. Percentage of households that received information about input markets from any source

\begin{tabular}{lcccc}
\hline & \multicolumn{2}{c}{$\mathbf{2 0 1 5}$} & \multicolumn{2}{c}{$\mathbf{2 0 1 7}$} \\
& Percent & Total HHs & Percent & Total HHs \\
\hline Control UPA Households & $31 \%$ & 949 & $60 \%$ & 860 \\
Treatment UPA Households & $39 \%$ & 933 & $59 \%$ & 889 \\
Total & $35 \%$ & 1,882 & $59 \%$ & 1,749 \\
\hline
\end{tabular}

Source: Authors' computation using InovAgro II baseline (2015) and midline (2017) datasets.

Table 4.2. Source from which information was received about input markets

\begin{tabular}{|c|c|c|c|c|c|c|}
\hline & \multicolumn{2}{|c|}{ Control } & \multicolumn{2}{|c|}{ Treatment } & \multicolumn{2}{|c|}{ Combined } \\
\hline & 2015 & 2017 & 2015 & 2017 & 2015 & 2017 \\
\hline Formal media (Radio / Newspaper / TV) & $3 \%$ & $22 \%$ & $11 \%$ & $22 \%$ & $7 \%$ & $22 \%$ \\
\hline $\begin{array}{l}\text { Relative (non-HH member) / Friend / } \\
\text { Neighbor }\end{array}$ & $10 \%$ & $40 \%$ & $11 \%$ & $45 \%$ & $10 \%$ & $42 \%$ \\
\hline $\begin{array}{l}\text { Formal / informal authority (Village leader / } \\
\text { Religious authority / Ag Association Leader / } \\
\text { Police / NGO) }\end{array}$ & $9 \%$ & $23 \%$ & $7 \%$ & $25 \%$ & $8 \%$ & $24 \%$ \\
\hline $\begin{array}{l}\text { Extension Agent / Input Seller / Agricultural } \\
\text { Goods Buyer }\end{array}$ & $13 \%$ & $17 \%$ & $17 \%$ & $29 \%$ & $15 \%$ & $23 \%$ \\
\hline Total number of households & 949 & 860 & 933 & 889 & 1,882 & 1,749 \\
\hline
\end{tabular}

Source: Authors' computation using InovAgro II baseline (2015) and midline (2017) datasets.

Such a differing picture of access to information between the two groups (control and treatment) becomes even more pronounced when comparisons are made between the mean differences of the two groups before and after the InovAgro II interventions. As shown in Table 4.3, the percentage of households reporting receipt of information about input markets from either extension agents or formal media (TV/Radio) jumped by about $26.8 \%$ for the beneficiary groups of the InovAgro II program, while in the control group, the percentage of households receiving information from one of these formal sources only increased by $18.7 \%$. 
Table 4.3. Implication of InovAgro on access to information about input markets

\begin{tabular}{lcccccc}
\hline & \multicolumn{3}{c}{ Treatment } & \multicolumn{2}{c}{ Control } \\
\cline { 2 - 6 } & $\begin{array}{c}\text { Baseline } \\
\text { (Before) }\end{array}$ & $\begin{array}{c}\text { Midline } \\
\text { (after) }\end{array}$ & Mean diff. & $\begin{array}{c}\text { Baseline } \\
\text { (Before) }\end{array}$ & $\begin{array}{l}\text { Midline } \\
\text { (after) }\end{array}$ & Mean diff. \\
\cline { 2 - 6 } & Mean/ $(\mathbf{S d})$ & Mean/ $(\mathbf{S d})$ & & Mean/ (Sd) & Mean/ (Sd) \\
\hline $\begin{array}{l}\text { Access to information } \\
\text { about inputs from formal }\end{array}$ & $25.8 \%$ & $52.6 \%$ & $0.268^{* * *}$ & $15.6 \%$ & $34.3 \%$ & $0.187^{* * *}$ \\
sources & $(0.44)$ & $(0.50)$ & & $(0.36)$ & $(0.50)$ & \\
\hline
\end{tabular}

Source: Authors' computation using InovAgro II baseline (2015) and midline (2017) datasets.

Note: This table compares the average effects on treatment and control households before and after the InovAgro II intervention. Statistical significance test where $* * *$ is $<=1 \%$, ** is $5 \%$ and $*$ is $10 \%$ level of significance. Standard deviations in parentheses.

Again, while many more households in both the control and the treatment group reported receiving input market information between 2015 and 2017, the share of control group informationreceiving households that reported that the information they received influenced a decision about from where or from whom they acquired any inputs increased by 13 percentage points (from $45 \%$ to $58 \%$ ), compared to a 20 percentage point increase in the share of households who received input market information in the treatment groups (from a lower $41 \%$ starting point, up to $71 \%$ ). Meanwhile, among those that received information and reported that it did influence a decision made concerning input acquisition, neither the control nor the treatment households reported much of an increase, if at all with respect to which agricultural inputs were acquired or whether agricultural inputs could be acquired at a better price or with better quality or timeliness. Rather the shares of households that found the market information they received in these three categories helpful, remained relatively high on average across both groups, at between 68 and 82 percent, consistently dropping off in the control UPAs (between 4 to 12 percentage points), while increasing in relevance in the treatment UPAs (between 11 and 16 percentage points, table 4.4).

Table 4.4. Households' stated effects of having received input market information on their behavior

\begin{tabular}{|c|c|c|c|c|c|c|}
\hline \multirow{2}{*}{$\begin{array}{l}\text { Did the information you received from } \\
\text { [MEDIUM]... }\end{array}$} & \multicolumn{2}{|c|}{ Control } & \multicolumn{2}{|c|}{ Treatment } & \multicolumn{2}{|c|}{ Combined } \\
\hline & 2015 & 2017 & 2015 & 2017 & 2015 & 2017 \\
\hline \multirow{2}{*}{$\begin{array}{l}\text { (1) influence any decision you may have made } \\
\text { regarding acquiring agricultural inputs? }\end{array}$} & $45 \%$ & $58 \%$ & $41 \%$ & $71 \%$ & $43 \%$ & $65 \%$ \\
\hline & $(131)$ & $(311)$ & $(150)$ & $(386)$ & $(281)$ & $(697)$ \\
\hline \multirow{2}{*}{$\begin{array}{l}\text { Total number of households that received information } \\
\text { about the input market (new input products, input } \\
\text { agricultural practices, input prices, input services, etc.) }\end{array}$} & $100 \%$ & $100 \%$ & $100 \%$ & $100 \%$ & $100 \%$ & $100 \%$ \\
\hline & $(291)$ & $(536)$ & $(397)$ & $(541)$ & $(658)$ & $(1,077)$ \\
\hline \multirow{2}{*}{$\begin{array}{l}\text { (2) make you change from where/whom you } \\
\text {...acquired any of your agricultural inputs? }\end{array}$} & $89 \%$ & $77 \%$ & $73 \%$ & $85 \%$ & $81 \%$ & $82 \%$ \\
\hline & $(117)$ & $(240)$ & $(110)$ & (329) & $(227)$ & (569) \\
\hline \multirow{2}{*}{$\begin{array}{l}\text { (3) make you change which agricultural inputs you } \\
\text { acquired? }\end{array}$} & $80 \%$ & $76 \%$ & $68 \%$ & $79 \%$ & $74 \%$ & $78 \%$ \\
\hline & (105) & (184) & (102) & (259) & (207) & $(443)$ \\
\hline \multirow{2}{*}{$\begin{array}{l}\text { (4) make it possible for you to acquire agricultural } \\
\text { inputs at a better price? }\end{array}$} & $83 \%$ & $74 \%$ & $63 \%$ & $79 \%$ & $72 \%$ & $77 \%$ \\
\hline & (109) & (178) & $(94)$ & (259) & (203) & $(437)$ \\
\hline \multirow{2}{*}{$\begin{array}{l}\text { (5) make it possible for you to acquire agricultural } \\
\text { inputs with a better quality or timeliness? }\end{array}$} & $77 \%$ & $71 \%$ & $59 \%$ & $74 \%$ & $68 \%$ & $73 \%$ \\
\hline & (101) & (177) & (89) & $(247)$ & (190) & $(424)$ \\
\hline $\begin{array}{r}\text { Total number of households for which information } \\
\text { influenced a decision made regarding acquiring } \\
\text { agricultural inputs }\end{array}$ & $\begin{array}{l}100 \% \\
(131)\end{array}$ & $\begin{array}{l}100 \% \\
(311)\end{array}$ & $\begin{array}{l}100 \% \\
(150)\end{array}$ & $\begin{array}{l}100 \% \\
(386)\end{array}$ & $\begin{array}{l}100 \% \\
(281)\end{array}$ & $\begin{array}{l}100 \% \\
(697)\end{array}$ \\
\hline
\end{tabular}

Source: Authors' computation using InovAgro II baseline (2015) and midline (2017) datasets.

Notes: Numbers in parentheses represent the frequency of household observations. Question 1 is the percentage of the total number of households that received information about the input market. Questions 2-5 are the percentages of the total number of households for which information about the input market was received and the respondent said it influenced a decision made regarding acquiring agricultural inputs. 
Similarly, "distrust of the information" did not increase among the reasons that were indicated for why market information did not affect households' decisions in the treatment areas, while "distrust of the information" did increase as a reason for why households in the control group did not make different decisions (12 to 19\%). Reasons that increased in popularity among the treatment group and the control group alike were "not understanding the information given", on average, this response grew by an average 17 percentage points, as well as "not finding the information relevant" (this response grew by an average 4 percentage points), both being runner-ups in frequency to the most commonly cited reason given in both year's surveys of "not having the means to change". This indicates that more relevant or more understandable information concerning input markets would help more farmers decide to make different decisions as it regards this area.

Reasons for which market information did not affect respondents' decisions continued to be attributed primarily, as in 2015, to the farmers' lack of the means to change (down, however, from the reason given by $44 \%$ of the responses by those who did receive input information from a given medium, but did not make any changes in 2015, to $27 \%$ across both treatment and control groups together in 2017 , table 4.5). Twenty-four percent of the responses given by households in the treatment areas that did not make any changes after receiving input information in 2015 said it was due to low quality or wrong information. This percentage dropped to $7 \%$ in 2017 , while in the control group, only $4 \%$ of responses were represented by this concern in 2015 , a share which rose to $5 \%$ as the main reason for not making a different decision in 2017. This shows that farmers only in the treatment group have increased confidence in the market information they receive, even if they have other reasons for not making decisions with respect to that information.

Table 4.5. Reasons why input market information did not affect households' decisions

\begin{tabular}{lcccccc}
\hline & \multicolumn{3}{c}{ Control } & \multicolumn{2}{c}{ Treatment } & \multicolumn{2}{c}{ Combined } \\
& $\mathbf{2 0 1 5}$ & $\mathbf{2 0 1 7}$ & $\mathbf{2 0 1 5}$ & $\mathbf{2 0 1 7}$ & $\mathbf{2 0 1 5}$ & $\mathbf{2 0 1 7}$ \\
\hline I did not trust the information & $12 \%$ & $19 \%$ & $16 \%$ & $16 \%$ & $14 \%$ & $18 \%$ \\
& $(29)$ & $(80)$ & $(52)$ & $(64)$ & $(81)$ & $(144)$ \\
Low quality/wrong information & $4 \%$ & $5 \%$ & $24 \%$ & $7 \%$ & $15 \%$ & $6 \%$ \\
& $(9)$ & $(22)$ & $(76)$ & $(29)$ & $(85)$ & $(51)$ \\
I did not understand the information & $7 \%$ & $26 \%$ & $6 \%$ & $20 \%$ & $6 \%$ & $23 \%$ \\
& $(16)$ & $(111)$ & $(20)$ & $(78)$ & $(36)$ & $(189)$ \\
I did not have the means to change my production & $59 \%$ & $25 \%$ & $33 \%$ & $29 \%$ & $44 \%$ & $27 \%$ \\
& $(141)$ & $(106)$ & $(106)$ & $(116)$ & $(247)$ & $(222)$ \\
It was not relevant to me & $18 \%$ & $21 \%$ & $21 \%$ & $26 \%$ & $20 \%$ & $24 \%$ \\
& $(44)$ & $(88)$ & $(66)$ & $(104)$ & $(110)$ & $(192)$ \\
Not Applicable & $0 \%$ & $4 \%$ & $0 \%$ & $1 \%$ & $0 \%$ & $2 \%$ \\
& $(0)$ & $(15)$ & $(0)$ & $(3)$ & $(0)$ & $(18)$ \\
Total & $100 \%$ & $100 \%$ & $100 \%$ & $100 \%$ & $100 \%$ & $100 \%$ \\
& $(239)$ & $(422)$ & $(320)$ & $(394)$ & $(559)$ & $(816)$ \\
\hline
\end{tabular}

Source: Authors' computation using InovAgro II baseline (2015) and midline (2017) datasets.

Note: Numbers in parentheses represent the frequency of household-medium observations.

\section{Access to Output Market Information}

Access to output market information is about as prevalent as access to input market information and is also increasing across all information sources by a similar factor as input market information is increasing (doubling from $30 \%$ to $62 \%$, table 4.6). The most common source of this information is, again, from the relatives/friends group (up to $45 \%$ from $11 \%$ in 2015 ), see table 4.7 . While $31 \%$ of households in the treatment group and $29 \%$ of the control group received output market information in 2015 , by $2017,64 \%$ of the households in the treatment group reported receiving output information by 2017 and $60 \%$ of those in the control group. The share of farmers that received output information in the 2017 survey is greater 
for the treatment group than for the control group across each of the four groupings of information sources.

Table 4.6. Percentage of households that received information about output markets from any source

\begin{tabular}{lcccc}
\hline & \multicolumn{2}{c}{2015} & \multicolumn{2}{c}{$\mathbf{2 0 1 7}$} \\
& Percent & Total HHs & Percent & Total HHs \\
\hline Control UPA Households & $29 \%$ & 949 & $60 \%$ & 860 \\
Treatment UPA Households & $31 \%$ & 933 & $64 \%$ & 889 \\
Total & $30 \%$ & 1,882 & $62 \%$ & 1,749 \\
\hline
\end{tabular}

Source: Authors' computation using InovAgro II baseline (2015) and midline (2017) datasets.

Table 4.7. Source from which information was received by households about output markets

\begin{tabular}{|c|c|c|c|c|c|c|}
\hline & \multicolumn{2}{|c|}{ Control } & \multicolumn{2}{|c|}{ Treatment } & \multicolumn{2}{|c|}{ Combined } \\
\hline & 2015 & 2017 & 2015 & 2017 & 2015 & 2017 \\
\hline Formal media (Radio / Newspaper / TV) & $1 \%$ & $20 \%$ & $3 \%$ & $23 \%$ & $2 \%$ & $21 \%$ \\
\hline Relative (non-HH member) / Friend / Neighbor & $12 \%$ & $40 \%$ & $9 \%$ & $50 \%$ & $11 \%$ & $45 \%$ \\
\hline $\begin{array}{l}\text { Formal / informal authority (Village leader / } \\
\text { Religious authority / Ag Association Leader / } \\
\text { Police / NGO) }\end{array}$ & $10 \%$ & $19 \%$ & $9 \%$ & $23 \%$ & $10 \%$ & $21 \%$ \\
\hline $\begin{array}{l}\text { Extension Agent / Input Seller / Agricultural } \\
\text { Goods Buyer }\end{array}$ & $13 \%$ & $17 \%$ & $10 \%$ & $31 \%$ & $12 \%$ & $24 \%$ \\
\hline Total number of households & 949 & 860 & 933 & 889 & 1,882 & 1,749 \\
\hline
\end{tabular}

Source: Authors' computation using InovAgro II baseline (2015) and midline (2017) datasets.

The statistical test for mean difference between the two groups (control and treatment) before and after the InovAgro II intervention (as shown in table 4.8) also supports the view of an implicit positive impact of the interventions on program beneficiary households as compared to non-beneficiary households (control). This before-after difference in the proportion of beneficiary households that gained more access to information about output markets from formal sources (extension agent and/or formal media) is almost double (12.5\%) that of non-beneficiary households (an increase by only $6.9 \%$ ).

Table 4.8. Implication of InovAgro on access to information about output markets

\begin{tabular}{|c|c|c|c|c|c|c|}
\hline & \multicolumn{3}{|c|}{ Treatment } & \multicolumn{3}{|c|}{ Control } \\
\hline & $\begin{array}{l}\text { Baseline } \\
\text { (Before) }\end{array}$ & $\begin{array}{l}\text { Midline } \\
\text { (after) }\end{array}$ & Mean diff. & $\begin{array}{l}\text { Baseline } \\
\text { (Before) }\end{array}$ & $\begin{array}{l}\text { Midline } \\
\text { (after) }\end{array}$ & Mean diff. \\
\hline & Mean/ (Sd) & Mean/ (Sd) & & Mean/ (Sd) & Mean/ (Sd) & \\
\hline $\begin{array}{l}\text { Access to information } \\
\text { about output markets from } \\
\text { formal source }\end{array}$ & $\begin{array}{l}12.2 \% \\
(0.33)\end{array}$ & $\begin{array}{l}24.7 \% \\
(0.43)\end{array}$ & $0.125^{* * *}$ & $\begin{array}{l}13.6 \% \\
(0.34)\end{array}$ & $\begin{array}{l}20.5 \% \\
(0.40)\end{array}$ & $0.069^{* * *}$ \\
\hline
\end{tabular}

Source: Authors' computation using InovAgro II baseline (2015) and midline (2017) datasets.

Note: This table compares the average effects on treatment and control households before and after the InovAgro II intervention. Standard deviations in parentheses.

Of households who received information about output markets, there was very little change in the percentage of households (63-66\%) that said the information they received affected a decision they could have taken in regards to production or sales (table 4.9). However the share of households that used the information they received to inform their decision-making in the control group declined from 71 to 70 percent, while the share of households in the treatment group increased from 60 to 77 percent. Among those that received information and reported that it did influence a decision made concerning their production or sales, there were decreases across both control and treatment groups, however, in the 
percentage that said the information (a) affected a decision to increase or decrease production of a crop (from $88 \%$ to $83 \%$ across both control and treatment groups combined), (b) affected a decision concerning where or who to sell their product to (from $89 \%$ to $73 \%$ ), (c) affected their ability to sell their product at an improved price ( $83 \%$ to $60 \%)$, or (d) affected their ability to sell a greater quantity to the same buyer had they not had the information ( $60 \%$ to $50 \%)$.

Table 4.9. Households' stated effects of having received output market information on their behavior

\begin{tabular}{|c|c|c|c|c|c|c|}
\hline \multirow{2}{*}{$\begin{array}{l}\text { Did the information you received from } \\
\text { [MEDIUM]... }\end{array}$} & \multicolumn{2}{|c|}{ Control } & \multicolumn{2}{|c|}{ Treatment } & \multicolumn{2}{|c|}{ Combined } \\
\hline & 2015 & 2017 & 2015 & 2017 & 2015 & 2017 \\
\hline \multirow{2}{*}{$\begin{array}{l}\text { (6) influence any decision you may have made } \\
\text { regarding production or sales during? }\end{array}$} & $71 \%$ & $70 \%$ & $60 \%$ & $77 \%$ & $66 \%$ & $63 \%$ \\
\hline & (192) & (364) & (139) & $(452)$ & (331) & $(816)$ \\
\hline $\begin{array}{l}\text { Total number of households that received information } \\
\text { about the output market (crop prices, output buyers, } \\
\text { crop transportation, output market sites, etc.) }\end{array}$ & $\begin{array}{l}100 \% \\
(272)\end{array}$ & $\begin{array}{l}100 \% \\
(519)\end{array}$ & $\begin{array}{l}100 \% \\
(231)\end{array}$ & $\begin{array}{l}100 \% \\
(585)\end{array}$ & $\begin{array}{l}100 \% \\
(503)\end{array}$ & $\begin{array}{c}100 \% \\
(1,104)\end{array}$ \\
\hline \multirow{2}{*}{$\begin{array}{l}\text { (7) affect your decision to increase/decrease certain } \\
\text { crop production? }\end{array}$} & $93 \%$ & $79 \%$ & $81 \%$ & $85 \%$ & $88 \%$ & 83 \\
\hline & (179) & (289) & (112) & (386) & (291) & (67 \\
\hline \multirow{2}{*}{$\begin{array}{l}\text { (8) affect your decision on where/to whom to sell your } \\
\text { harvested crops? }\end{array}$} & $91 \%$ & $68 \%$ & $86 \%$ & $77 \%$ & $89 \%$ & $73 \%$ \\
\hline & (174) & (246) & (119) & (346) & (293) & (592) \\
\hline \multirow{2}{*}{$\begin{array}{l}\text { (9) make it possible for you to sell your harvested } \\
\text { crops for a better price than you otherwise would } \\
\text { have been able to? }\end{array}$} & $83 \%$ & $55 \%$ & $82 \%$ & $63 \%$ & $83 \%$ & $60 \%$ \\
\hline & (160) & (200) & (114) & (285) & (274) & $(485)$ \\
\hline \multirow{2}{*}{$\begin{array}{l}\text { (10) make it possible for you to sell more to the same } \\
\text { buyer than you otherwise would have been able to? }\end{array}$} & $59 \%$ & $45 \%$ & $62 \%$ & $54 \%$ & $60 \%$ & $50 \%$ \\
\hline & (113) & (165) & (86) & (243) & (199) & (408) \\
\hline $\begin{array}{r}\text { Total number of households for which information } \\
\text { influenced a decision made regarding production or } \\
\text { sales }\end{array}$ & $\begin{array}{l}100 \% \\
(192)\end{array}$ & $\begin{array}{l}100 \% \\
(364)\end{array}$ & $\begin{array}{l}100 \% \\
(139)\end{array}$ & $\begin{array}{l}100 \% \\
(452)\end{array}$ & $\begin{array}{l}100 \% \\
(331)\end{array}$ & $\begin{array}{l}100 \% \\
(816)\end{array}$ \\
\hline
\end{tabular}

Source: Authors' computation using InovAgro II baseline (2015) and midline (2017) datasets.

Notes: Numbers in parentheses represent the frequency of household observations. Question 6 is the percentage of the total number of households that received information about the output market. Questions 2-5 are the percentages of the total number of households for which information about the output market was received and the respondent said it influenced a decision made regarding production or sales.

Reasons for which this information did not affect their decisions shifted from the top reason in 2015 being that the information was of low or erroneous quality (from $30 \%$ of responses that received such information to $6 \%$ ), to other top reasons given in 2015, including those expressing that they were not able to change (from $26 \%$ to $27 \%$ ), and those who found the information provided was irrelevant (from $22 \%$ to $24 \%$ of responses, see table 4.10 ). There was also an increase from $8 \%$ to $22 \%$ of responses of not understanding the information, and a smaller increase, from $14 \%$ to $20 \%$, of responses of not trusting the information provided. In the treatment group, $43 \%$ of households' responses in the 2015 survey that received output information but it did not influence any sale or production decision they made, stated this was because they felt that the information they received was of low quality or just wrong, while this represented only $10 \%$ of responses in the control group. By 2017, not only were there more farmers who received market information in the treatment group, but only $7 \%$ of these farmers' responses indicated that they felt that the information was erroneous. Likewise, the share of responses among those in the control group dropped from $10 \%$ to $5 \%$. 
Table 4.10. Reasons why output market information did not affect households' decisions

\begin{tabular}{|c|c|c|c|c|c|c|}
\hline & \multicolumn{2}{|c|}{ Control } & \multicolumn{2}{|c|}{ Treatment } & \multicolumn{2}{|c|}{ Combined } \\
\hline & 2015 & 2017 & 2015 & 2017 & 2015 & 2017 \\
\hline \multirow[t]{2}{*}{ I did not trust the information } & $9 \%$ & $23 \%$ & $17 \%$ & $16 \%$ & $14 \%$ & $20 \%$ \\
\hline & $(10)$ & $(77)$ & $(29)$ & $(65)$ & (39) & $(142)$ \\
\hline \multirow[t]{2}{*}{ Low quality/wrong information } & $10 \%$ & $5 \%$ & $43 \%$ & $7 \%$ & $30 \%$ & $6 \%$ \\
\hline & $(11)$ & $(16)$ & $(73)$ & $(27)$ & (84) & $(43)$ \\
\hline \multirow[t]{2}{*}{ I did not understand the information } & $6 \%$ & $22 \%$ & $10 \%$ & $22 \%$ & $8 \%$ & $22 \%$ \\
\hline & $(7)$ & $(71)$ & $(16)$ & $(86)$ & (23) & (157) \\
\hline \multirow[t]{2}{*}{ I did not have the means to change my production } & $46 \%$ & $24 \%$ & $13 \%$ & $29 \%$ & $26 \%$ & $27 \%$ \\
\hline & $(52)$ & $(80)$ & $(21)$ & (116) & $(73)$ & (196) \\
\hline \multirow[t]{2}{*}{ It was not relevant to me } & $30 \%$ & $23 \%$ & $17 \%$ & $25 \%$ & $22 \%$ & $24 \%$ \\
\hline & (34) & $(75)$ & $(29)$ & $(97)$ & (63) & $(172)$ \\
\hline \multirow[t]{2}{*}{ Not Applicable } & $0 \%$ & $3 \%$ & $0 \%$ & $1 \%$ & $0 \%$ & $2 \%$ \\
\hline & $(0)$ & $(9)$ & $(0)$ & $(4)$ & $(0)$ & (13) \\
\hline \multirow[t]{2}{*}{ Total } & $100 \%$ & $100 \%$ & $100 \%$ & $100 \%$ & $100 \%$ & $100 \%$ \\
\hline & $(114)$ & $(328)$ & $(168)$ & (395) & $(282)$ & $(723)$ \\
\hline
\end{tabular}

Source: Authors' computation using InovAgro II baseline (2015) and midline (2017) datasets.

Note: Numbers in parentheses represent the frequency of household-medium observations.

In the control group, farmers noted that their challenge with implementing market information had less to do with not having the means (from 46\% giving this reason in 2015 to $24 \%$ giving this reason in 2017), while in the treatment group, the response of not having the means to change production rose from 13 to 29 percent. Similarly, the farmers in the control group who received information felt less that it had to do with it relevance (the percentage of those who said the information was not relevant decreased from 30 to 23 percent), while those in the treatment group who did not implement a change, found the information increasingly irrelevant (from 17 to 25 percent).

The share of households growing crops on contract in the previous year increased (from $2.4 \%$ in 2015 to $14.2 \%$ in 2017), as did the share of households using a tractor (from $0.2 \%$ in 2015 to $5.0 \%$ in 2017). Most of the farmers rented tractors from an association (29\%) or an agri-service provider (25\%), but a good portion also purchased them using their savings (22\%).

Again, in addition to the implications that the InovAgro interventions are contributing to better access to information (both input and output markets) for beneficiary households as compared to nonbeneficiary households, the preliminary descriptive results also imply that the program is having a positive effect as it regards the evidenced increased extension services by way of farmers' participation in field days and visits to demo plots. As results reported in table 4.11 show, though both groups evidence a significant enhancement in access to such extension services, the proportional increase before-and-after the InovAgro II project is significantly higher for beneficiary households in terms of visits to demo plots (an increase by $22.6 \%$ for beneficiaries but only by $14.1 \%$ for control households). On the other hand, there seems very little difference between the two groups in terms of participation in field days, as the proportional increase before-and-after the InovAgro intervention is just $16.7 \%$ and $12.3 \%$ for beneficiary and non-beneficiary households, respectively. 
Table 4.11. Implication of InovAgro on access to extension services

\begin{tabular}{|c|c|c|c|c|c|c|}
\hline & \multicolumn{3}{|c|}{ Treatment } & \multicolumn{3}{|c|}{ Control } \\
\hline & $\begin{array}{l}\text { Baseline } \\
\text { (Before) }\end{array}$ & $\begin{array}{c}\text { Midline } \\
\text { (after) }\end{array}$ & Mean diff. & $\begin{array}{l}\text { Baseline } \\
\text { (Before) }\end{array}$ & $\begin{array}{l}\text { Midline } \\
\text { (after) }\end{array}$ & Mean diff. \\
\hline & Mean/ (Sd) & Mean/ (Sd) & & Mean/ (Sd) & Mean/ (Sd) & \\
\hline \multirow{2}{*}{$\begin{array}{l}\text { Households who } \\
\text { participated in field days }\end{array}$} & $1.4 \%$ & $18.1 \%$ & $0.167^{* * *}$ & $1.8 \%$ & $14.1 \%$ & $0.123^{* * *}$ \\
\hline & $(0.12)$ & $(0.39)$ & & $(0.13)$ & $(0.35)$ & \\
\hline \multirow{2}{*}{$\begin{array}{l}\text { Households who visited } \\
\text { demo plots }\end{array}$} & $0.5 \%$ & $23.1 \%$ & $0.226^{* * *}$ & $0.7 \%$ & $14.9 \%$ & $0.141^{* * *}$ \\
\hline & $(0.07)$ & $(0.42)$ & & $(0.09)$ & $(0.36)$ & \\
\hline
\end{tabular}

Source: Authors' computation using InovAgro II baseline (2015) and midline (2017) datasets.

Note: This table compares the average effects on treatment and control households before and after the InovAgro II intervention. Statistical significance test where $* * *$ is $<=1 \%, * *$ is $5 \%$ and $*$ is $10 \%$ level of significance. Standard deviations in parentheses.

\section{Access to input and output markets}

Taking into account the major intervention arms of the InovAgro program (enhancing smallholder farmers' access to input and output markets), we also conducted mean comparison tests of performance by the two groups (treatment and control), before and after the InovAgro program. Tables 4.12 and 4.13 below present the mean comparison analysis for input market and output market access, respectively.

\section{Access to input markets (adoption of improved/certified seed variety)}

Results from table 4.12 show an increase over time in adoption of certified seed varieties of the two value chain crops for both treatment and control households (perhaps, an indication of spillover benefits of programs such as the InovAgro). However, when comparisons were made across the percentage increase in the adoption rates of such improved varieties, the descriptive results show that the relative increase is larger for beneficiary households (especially, for soybean-i.e. by 16.6\%) as compared to non-beneficiary farmers (i.e., only $9.6 \%$ for soybean). On the other hand, such contrasting evidence is not so when comparisons are made among beneficiary and non-beneficiary households. This is so since the relative increase in adoption of certified pigeon pea seed before-and-after the InovAgro intervention is not as wide as that of the difference for soybean, i.e., only by $6.8 \%$ for beneficiaries and $4.1 \%$ for non-beneficiaries. Also using the likelihood of using hired labor as a proxy indicator for input market integration among smallholder farmers, results show that beneficiary households' proportion of hired labor use has increased by about almost $10 \%$ (comparing before-and-after the implementation of the InovAgro program), while that of non-beneficiary households remains almost stagnant-i.e., an increase by just $0.1 \%$.

Table 4.12. Implication of InovAgro on smallholder farmers' input market integration

\begin{tabular}{|c|c|c|c|c|c|c|}
\hline & \multicolumn{3}{|c|}{ Treatment } & \multicolumn{3}{|c|}{ Control } \\
\hline & $\begin{array}{l}\text { Baseline } \\
\text { (Before) }\end{array}$ & $\begin{array}{c}\text { Midline } \\
\text { (after) }\end{array}$ & Mean diff. & $\begin{array}{l}\text { Baseline } \\
\text { (Before) }\end{array}$ & $\begin{array}{c}\text { Midline } \\
\text { (after) }\end{array}$ & Mean diff. \\
\hline & $\begin{array}{c}\text { Mean/ } \\
(\text { Sd) }\end{array}$ & $\begin{array}{c}\text { Mean/ } \\
(\mathrm{Sd})\end{array}$ & & $\begin{array}{c}\text { Mean/ } \\
\text { (Sd) }\end{array}$ & $\begin{array}{c}\text { Mean/ } \\
(\mathrm{Sd})\end{array}$ & \\
\hline \multirow{2}{*}{$\begin{array}{l}\text { Hired labor used for any farm } \\
\text { activity - dummy }\end{array}$} & $20.5 \%$ & $29.9 \%$ & $0.094^{* * *}$ & $23.0 \%$ & $23.1 \%$ & 0.001 \\
\hline & $(0.40)$ & $(0.46)$ & & $(0.42)$ & $(0.42)$ & \\
\hline \multirow{2}{*}{$\begin{array}{l}\text { Has adopted improved seed for } \\
\text { soybean }\end{array}$} & $1.3 \%$ & $17.9 \%$ & $0.166^{* * *}$ & $0.2 \%$ & $9.8 \%$ & $0.096^{* * *}$ \\
\hline & $(0.11)$ & $(0.38)$ & & 0.05 & $(0.30)$ & \\
\hline \multirow{2}{*}{$\begin{array}{l}\text { Has adopted improved seed for } \\
\text { pigeon pea }\end{array}$} & $1.3 \%$ & $8.1 \%$ & $0.068^{* * *}$ & $0.4 \%$ & $4.5 \%$ & $0.041^{* * *}$ \\
\hline & $(0.11)$ & $(0.27)$ & & 0.06 & $(0.21)$ & \\
\hline \multirow{2}{*}{$\begin{array}{l}\text { Has adopted improved seed for } \\
\text { either of the two VC crops }\end{array}$} & $8.0 \%$ & $28.7 \%$ & $0.206^{* * *}$ & $1.4 \%$ & $19.4 \%$ & $0.180^{\star \star \star}$ \\
\hline & $(0.27)$ & $(0.45)$ & & $(0.12)$ & $(0.40)$ & \\
\hline
\end{tabular}

Source: Authors' computation using InovAgro II baseline (2015) and midline (2017) datasets.

Note: This table compares the average effects on treatment and control households before and after the InovAgro II intervention. Statistical significance test where $* * *$ is $<=1 \%, * *$ is $5 \%$ and $*$ is $10 \%$ level of significance. Standard deviations in parentheses. 


\section{Access to output markets (participation in the sale of value chain crops)}

Similar to the impact of the InovAgro program on smallholder input market integration, the impact of the program on facilitating smallholder farmers' access to output market is more pronounced for participation in the soybean value chain as compared to the value chains of pigeon pea and maize. This is shown by the mean comparison test results presented in table 4.13. This possibly shows the sustainability in production of the soybean crop and the potential crop specialization effect of the InovAgro activities, given that the proportional increase in the number of households who reported to have sold a soybean product (comparing before and after the implementation of the InovAgro program) is significantly higher among beneficiary households (by almost 13\%) compared to non-beneficiary households, among which only $7.6 \%$ reported the sale of soybean product. On the other hand, the opposite is true when similar comparisons are made for participation in the pigeon pea and maize value chains. That is, the proportional increase in the percentage of households that marketed their production of either of these two crops is significantly larger for non-beneficiary households as compared to beneficiary households. This result could be indicative of a specialization in the soybean value chain by InovAgro beneficiary households as compared to those non-beneficiary households.

Table 4.13. Implication of InovAgro on smallholder farmers' output market integration

\begin{tabular}{|c|c|c|c|c|c|c|}
\hline & \multicolumn{3}{|c|}{ Treatment } & \multicolumn{3}{|c|}{ Control } \\
\hline & $\begin{array}{l}\text { Baseline } \\
\text { (Before) }\end{array}$ & $\begin{array}{l}\text { Midline } \\
\text { (after) }\end{array}$ & Mean diff. & $\begin{array}{l}\text { Baseline } \\
\text { (Before) }\end{array}$ & $\begin{array}{l}\text { Midline } \\
\text { (after) }\end{array}$ & Mean diff. \\
\hline & Mean/ (Sd) & Mean/ (Sd) & & Mean/ (Sd) & Mean/ (Sd) & \\
\hline \multirow{2}{*}{$\begin{array}{l}\text { Sold soybean grown in most } \\
\text { recent year's season }\end{array}$} & $1.3 \%$ & $14.1 \%$ & $0.128^{* * *}$ & $1.2 \%$ & $8.7 \%$ & $0.076^{\star \star *}$ \\
\hline & $(0.11)$ & $(0.35)$ & & $(0.11)$ & $(0.28)$ & \\
\hline \multirow{2}{*}{$\begin{array}{l}\text { Sold PP grown in most recent } \\
\text { year's season }\end{array}$} & $30.8 \%$ & $33.0 \%$ & 0.022 & $38.4 \%$ & $25.2 \%$ & $-0.131^{* * *}$ \\
\hline & $(0.46)$ & $(0.47)$ & & $(0.49)$ & $(0.43)$ & \\
\hline \multirow{2}{*}{$\begin{array}{l}\text { Sold maize grown in most } \\
\text { recent year's season }\end{array}$} & $20.4 \%$ & $23.1 \%$ & 0.027 & $8.6 \%$ & $17.1 \%$ & $0.085^{* * *}$ \\
\hline & $(0.40)$ & $(0.42)$ & & $(0.28)$ & $(0.38)$ & \\
\hline
\end{tabular}

Source: Authors' computation using InovAgro-II baseline (2015) and midline (2017) datasets.

Note: This table compares the average effects on treatment and control households before and after the InovAgro II intervention. Statistical significance test where $* * *$ is $<=1 \%$, ** is $5 \%$ and $*$ is $10 \%$ level of significance. Standard deviations in parentheses.

\section{Potential long-term impacts: program impact on livelihood diversification}

Using rural-urban migration as well as engagement in the non-farm sector as two proxy variables for assessing the potential welfare implications of the InovAgro program, we conducted mean comparison tests before-and-after the implementation of the program for both beneficiary and non-beneficiary households. Results from table 4.14 below, show that there is a significant positive implication of the InovAgro program on beneficiary households compared to non-beneficiary households in terms of all the proxy variables used. Such relative benefit is more pronounced when comparisons are made in terms of the relative increase in the proportion of households with at least one member reported to be engaged in non-farm activity (i.e., an increase from $58.9 \%$ for beneficiary households, where there is a slight decrease from $45.9 \%$ to $41.5 \%$ for non-beneficiary households). 
Table 4.14. Implication of InovAgro on livelihood diversification

\begin{tabular}{|c|c|c|c|c|c|c|}
\hline & \multicolumn{3}{|c|}{ Treatment } & \multicolumn{3}{|c|}{ Control } \\
\hline & $\begin{array}{l}\text { Baseline } \\
\text { (Before) }\end{array}$ & $\begin{array}{l}\text { Midline } \\
\text { (after) }\end{array}$ & $\begin{array}{c}\text { Mean } \\
\text { diff. }\end{array}$ & $\begin{array}{l}\text { Baseline } \\
\text { (Before) }\end{array}$ & $\begin{array}{l}\text { Midline } \\
\text { (after) }\end{array}$ & Mean diff. \\
\hline & $\begin{array}{l}\text { Mean/ } \\
(\text { Sd) }\end{array}$ & $\begin{array}{l}\text { Mean/ } \\
(\text { Sd) }\end{array}$ & & $\begin{array}{l}\text { Mean/ } \\
\text { (Sd) }\end{array}$ & $\begin{array}{l}\text { Mean/ } \\
\text { (Sd) }\end{array}$ & \\
\hline \multirow{4}{*}{$\begin{array}{l}\text { Head and/or spouse with a non- } \\
\text { farm primary or secondary } \\
\text { activity } \\
\text { At least one member has a non- } \\
\text { farm activity }\end{array}$} & $40.7 \%$ & $46.2 \%$ & $0.055^{*}$ & $45.9 \%$ & $41.5 \%$ & -0.044 \\
\hline & $(0.49)$ & $(0.50)$ & & $(0.50)$ & $(0.49)$ & \\
\hline & $58.9 \%$ & $71.2 \%$ & $0.123^{* \star *}$ & $61.4 \%$ & $66.6 \%$ & $0.052^{*}$ \\
\hline & $(0.49)$ & $(0.45)$ & & $(0.49)$ & $(0.47)$ & \\
\hline \multirow{2}{*}{$\begin{array}{l}\text { At least one member is } \\
\text { temporary migrant }\end{array}$} & $14.7 \%$ & $44.9 \%$ & $0.302^{* * *}$ & $12.3 \%$ & $39.0 \%$ & $0.266^{* * *}$ \\
\hline & $(0.35)$ & $(0.50)$ & & $(0.33)$ & $(0.49)$ & \\
\hline \multirow{2}{*}{$\begin{array}{l}\text { At least one member is a } \\
\text { permanent migrant }\end{array}$} & $0.0 \%$ & $11.9 \%$ & $0.119^{\star * \star}$ & $0.0 \%$ & $9.1 \%$ & $0.091^{* * *}$ \\
\hline & $(0.00)$ & $(0.32)$ & & $(0.00)$ & $(0.29)$ & \\
\hline \multirow{2}{*}{$\begin{array}{l}\mathrm{HH} \text { has a temporary migrant } \\
\text { head or spouse }\end{array}$} & $9.1 \%$ & $36.8 \%$ & $0.277^{* * *}$ & $9.5 \%$ & $32.3 \%$ & $0.228^{* * *}$ \\
\hline & $(0.29)$ & $(0.48)$ & & $(0.29)$ & $(0.47)$ & \\
\hline \multirow{2}{*}{$\begin{array}{l}\mathrm{HH} \text { has a permanent migrant } \\
\text { head or spouse }\end{array}$} & $0.0 \%$ & $2.4 \%$ & $0.024^{* * *}$ & $0.0 \%$ & $2.0 \%$ & $0.020^{* * *}$ \\
\hline & $(0.00)$ & $(0.15)$ & & $(0.00)$ & $(0.14)$ & \\
\hline \multirow{2}{*}{$\begin{array}{l}\text { Number of member-temporary } \\
\text { migrants }\end{array}$} & $17.4 \%$ & $70.5 \%$ & $0.532^{* * *}$ & $15.0 \%$ & $58.0 \%$ & $0.431^{* * *}$ \\
\hline & $(0.45)$ & $(0.95)$ & & $(0.43)$ & $(0.87)$ & \\
\hline \multirow{2}{*}{$\begin{array}{l}\text { Number of member-permanent } \\
\text { migrants }\end{array}$} & $0.0 \%$ & $17.0 \%$ & $0.170^{* * *}$ & $0.0 \%$ & $13.3 \%$ & $0.133^{* * *}$ \\
\hline & $(0.00)$ & $(0.53)$ & & $(0.00)$ & $(0.47)$ & \\
\hline
\end{tabular}

Source: Authors' computation using InovAgro-II baseline (2015) and midline (2017) datasets.

Note: This table compares the average effects on treatment and control households before and after the InovAgro II intervention. Statistical significance test where $* * *$ is $<=1 \%, * *$ is $5 \%$ and $*$ is $10 \%$ level of significance. Standard deviations in parentheses.

\section{Comparisons between treatment and control communities over time}

Table 4.15 summarizes comparisons of short-term outcome variables between community exposure to the InovAgro II project and those not exposed. This table shows that the share of households that sold any of their produced crops in the latest agricultural season is statistically higher in the treatment communities than in the control communities in both 2015 and 2017 (43\% in control group versus $48 \%$ in treatment group in 2015 and $35 \%$ in control group versus $45 \%$ in treatment group in 2017). This finding suggests that the share of households that sell one or more crops declined between 2015 and 2017 for both treatment and control communities. By contrast, the proportion of households who sold soybean and pigeon pea, the key crops promoted by the InovAgro II project, increased among households who were beneficiaries of the InovAgro II project: from 1\% in 2015 to $14 \%$ in 2017 for soybean and from $31 \%$ in 2015 to 33\% in 2017 for pigeon pea. Among households who were not beneficiaries, the proportion of households that sold soybean increased to a lesser degree, from 1\% in 2015 to $9 \%$ in 2017, while the proportion of households that sold pigeon pea declined from 38\% in 2015 to $25 \%$ in 2017 .

Table 4.15 reveals that the proportion of soybean-selling households are statistically equal between treatment and control communities in 2015 (p-value $=0.7640)$, but the proportion differs significantly ( $p$-value $=0.0006$ ) between treatment and control communities in 2017 , being considerably higher in treatment communities ( $9 \%$ versus $14 \%$ ). This table also illustrates that the proportion of pigeon pea-selling households is statistically different ( $p$-value $=0.0013$ in 2015 versus a $p$-value $=0.0004$ in 2017) between treatment and control communities. As is the case with soybean, the share of pigeon pea sellers is greater in the treatment than in the control communities in 2017. These findings suggest that exposure to the InovAgro II project resulted in increased proportions of households that sold soybean and pigeon pea. 
Table 4.15. Comparisons between treatment and control communities: Short-term outcome indicators

\begin{tabular}{|c|c|c|c|c|c|c|}
\hline \multirow{3}{*}{ Outcome variable } & \multicolumn{2}{|c|}{ Baseline 2015} & \multicolumn{4}{|c|}{ Midline 2017} \\
\hline & Control & Treatment & $\begin{array}{l}\text { Mean diff } \\
\text { p-value }\end{array}$ & Control & Treatment & $\begin{array}{c}\text { Mean diff } \\
p \text {-value }\end{array}$ \\
\hline & Mean/ (Sd) & Mean/ (Sd) & & Mean/ (Sd) & Mean/ (Sd) & \\
\hline \multirow[t]{2}{*}{ Sold any crop from most recent season (1 = yes, 0 otherwise) } & 0.4323 & 0.4786 & 0.0455 & 0.3520 & 0.4472 & 0.0001 \\
\hline & $(0.0161)$ & $(0.0166)$ & & $(0.0165)$ & $(0.0168)$ & \\
\hline \multirow[t]{2}{*}{ Sold soybean from most recent season ( 1 = yes, 0 otherwise) } & 0.0116 & 0.0132 & 0.7640 & 0.0892 & 0.1419 & 0.0006 \\
\hline & $(0.0035)$ & $(0.0038)$ & & $(0.0098)$ & $(0.0118)$ & \\
\hline \multirow{2}{*}{ Sold pigeon pea from most recent season ( 1 = yes, 0 otherwise) } & 0.3837 & 0.3128 & 0.0013 & 0.2545 & 0.3314 & 0.0004 \\
\hline & $(0.0158)$ & $(0.0154)$ & & $(0.0150)$ & $(0.0159)$ & \\
\hline \multirow[t]{2}{*}{ Adopted improved seed for soybean ( 1 = yes, 0 otherwise) } & 0.0021 & 0.0132 & 0.0066 & 0.0987 & 0.1793 & 0.0000 \\
\hline & $(0.0015)$ & $(0.0038)$ & & $(0.0103)$ & $(0.0129)$ & \\
\hline \multirow{2}{*}{ Adopted improved seed for pigeon pea (1 = yes, 0 otherwise) } & 0.0042 & 0.0132 & 0.0390 & 0.0464 & 0.0806 & 0.0035 \\
\hline & $(0.0021)$ & $(0.0038)$ & & $(0.0073)$ & $(0.0092)$ & \\
\hline \multirow[t]{2}{*}{ Production value for soybean, pigeon pea and maize (thousand MZN) } & 85.8706 & 24.7456 & 0.0000 & 4.6888 & 4.9880 & 0.6310 \\
\hline & $(4.7197)$ & (1.1995) & & $(0.4743)$ & $(0.4036)$ & \\
\hline \multirow{2}{*}{$\begin{array}{l}\text { Access to output market information from formal sources }(1=\text { yes, } 0 \\
\text { otherwise) }\end{array}$} & 0.1364 & 0.1251 & 0.4733 & 0.2069 & 0.2497 & 0.0342 \\
\hline & $(0.0112)$ & $(0.0110)$ & & $(0.0140)$ & $(0.0146)$ & \\
\hline \multirow[t]{2}{*}{ Hired labor for any farming activity ( 1 = yes, 0 otherwise) } & 0.2304 & 0.2064 & 0.2094 & 0.2307 & 0.2997 & 0.0012 \\
\hline & $(0.0137)$ & $(0.0134)$ & & $(0.0145)$ & $(0.0154)$ & \\
\hline Observations & 946 & 911 & & 841 & 881 & \\
\hline
\end{tabular}

Source: Authors' computation using InovAgro-II baseline (2015) and midline (2017) datasets.

Note: Standard deviations in parentheses. 
Table 4.15 illustrates that the shares of households that used improved seed of both soybean and pigeon pea are statistically higher in the treatment communities than in the control communities in 2015 and $2017(0.2 \%$ versus $1 \%$ in 2015 and $10 \%$ versus $18 \%$ in 2017 for soybean and $0.4 \%$ versus $1 \%$ in 2015 and 5\% versus 8\% in 2017 for pigeon pea). This suggests that interventions through the InovAgro II project promoted use of improved seed for both soybean and pigeon pea. This increased usage of improved soybean and pigeon pea seed among beneficiaries of the InovAgro II project could be associated with the increased sales of both crops outlined in the previous paragraph.

The shares of households with access to output markets are not statistically different ( $\mathrm{p}$-value $=$ 0.4733 ) between treatment (with 13\%) and control (with 14\%) communities in 2015; however, these shares are statistically different ( $\mathrm{p}$-value $=0.0342)$ between the two communities in $2017(21 \%$ in control communities versus $25 \%$ in treatment communities). Similar patterns but with different magnitudes are registered for the shares of households that hired labor for any farming activity. These findings suggest that exposure to the InovAgro II project could have resulted in increased proportions of households with access to output market information and that hired labor for farming activities.

Table 4.16 summarizes mean comparisons between treatment and control communities over time for long term outcome variables. This table shows that the proportions of households who had a temporary migrant head or spouse are not statistically different $(p$-value $=0.8285)$ between treatment and control communities in 2015; however, these proportions are statistically different in both communities in 2017 (p-value $=0.0691)$, being higher in the treatment communities $(33 \%$ in control communities versus $37 \%$ in the treatment communities). Similar patterns but with different magnitudes are observed for the number of temporary migrants, the share of households with heads or spouses engaged in nonfarm activities as primary or secondary activities, and the household asset index. These findings could indicate that exposure to the InovAgro II project strengthened long-term outcome variables. 
Table 4.16. Comparisons between the baseline and midline surveys: Long-term outcome indicators

\begin{tabular}{|c|c|c|c|c|c|c|}
\hline \multirow{3}{*}{ Outcome variable } & \multicolumn{3}{|c|}{ Baseline 2015} & \multicolumn{3}{|c|}{ Midline 2017} \\
\hline & Control & Treatment & $\begin{array}{l}\text { Mean diff } \\
\text { p-value }\end{array}$ & Control & Treatment & $\begin{array}{c}\text { Mean diff } \\
p \text {-value }\end{array}$ \\
\hline & Mean/ (Sd) & Mean/ (Sd) & & Mean/ (Sd) & Mean/ (Sd) & \\
\hline \multirow[t]{2}{*}{ Had a temporary migrant head or spouse ( $1=$ yes, 0 otherwise $)$} & 0.0951 & 0.0922 & 0.8285 & 0.3294 & 0.3712 & 0.0691 \\
\hline & $(0.0095)$ & $(0.0096)$ & & $(0.0162)$ & $(0.0163)$ & \\
\hline \multirow[t]{2}{*}{ Number of temporary migrants } & 0.1490 & 0.1767 & 0.1815 & 0.5910 & 0.7117 & 0.0061 \\
\hline & $(0.0141)$ & $(0.0152)$ & & $(0.0300)$ & $(0.0321)$ & \\
\hline \multirow[t]{2}{*}{ Head or spouse with nonfarm primary or secondary activity ( $1=$ yes, 0 otherwise) } & 0.4588 & 0.4105 & 0.0361 & 0.4209 & 0.4642 & 0.0705 \\
\hline & $(0.0162)$ & $(0.0163)$ & & $(0.0170)$ & $(0.0168)$ & \\
\hline \multirow{2}{*}{ Asset index-functioning items } & -0.1027 & -0.0529 & 0.3585 & 0.0068 & 0.1689 & 0.0000 \\
\hline & $(0.0357)$ & $(0.0409)$ & & $(0.0241)$ & $(0.0284)$ & \\
\hline \multirow[t]{2}{*}{ Asset index-including non-functioning items } & -0.2602 & -0.2110 & 0.3069 & 0.1816 & 0.3308 & 0.0005 \\
\hline & $(0.0319)$ & $(0.0361)$ & & $(0.0275)$ & $(0.0327)$ & \\
\hline \multirow[t]{2}{*}{ Asset index-only functioning durable items } & -0.1269 & -0.1432 & 0.7470 & 0.0743 & 0.2231 & 0.0004 \\
\hline & $(0.0369)$ & $(0.0344)$ & & $(0.0286)$ & $(0.0304)$ & \\
\hline \multirow[t]{2}{*}{ Asset index-including non-functioning durable items } & -0.2830 & -0.2936 & 0.8078 & 0.2448 & 0.3803 & 0.0033 \\
\hline & $(0.0320)$ & $(0.0298)$ & & $(0.0307)$ & $(0.0345)$ & \\
\hline Observations & 946 & 911 & & 841 & 881 & \\
\hline
\end{tabular}

Source: Authors' computation based on InovAgro II baseline (2015) and midline (2017) datasets.

Note: Standard deviations in parentheses. 


\section{ECONOMETRIC RESULTS}

\section{Impact of the InovAgro II project on short term outcome variables}

Table 5.1 illustrates estimates of the impact of the InovAgro II project on short term outcome variables using regression analysis. As explained earlier, we employ three regression approaches. First, DID regression, which assumes that randomization of the treatment and control would allow us to estimate the impact of the InovAgro II project without controlling for household-level covariates (model 1). Second, we control for covariates that could influence the difference in trends between treatment and control communities (model 2). Finally, we control for potential selection bias (model 3). Based on model 1, exposure to the InovAgro II project did not have any impact on whether households sold any crop produced in the last season. However, when we control for covariates (model 2 and 3), the share of households that sold any crop produced in the last season are higher among treatment communities than among control communities. All three regression approaches indicate that exposure to the InovAgro II project increased the share of households selling soybean by about $5 \%$ and those selling pigeon pea by about $16 \%$. This suggests that the impact of the InovAgro II project on crop sales is substantially higher for pigeon pea compared to soybean.

The InovAgro II project appears to have had a positive impact on the usage of improved seed for both soybean and pigeon pea among households who benefited from InovAgro II project, with a greater impact on the usage of soybean than on that of pigeon pea. Findings presented in Table 5.1 indicate that as a result of exposure to the InovAgro II project, the proportion of households using improved seed increased, with a greater increase in the use of soybean (about $6 \%$ ) than pigeon pea (about $2 \%$ ).

Furthermore, our econometric analysis consistently suggests that among farmers who benefited from the InovAgro II project, the total value of production for soybean, pigeon pea and maize increased by approximately 67 thousand Mozambican New Meticais (MZN). This higher production value could be associated with the positive impact on access to output market information offered by exposure to the InovAgro II project, especially market information obtained from formal sources. Table 5.1 indicates that the proportion of households that obtained output market information from formal sources is approximately 5\% higher among households which benefited from the InovAgro II project than among those which did not benefit.

Exposure to the InovAgro II project appears to have increased the share of households that hired labor for any farming activity by about $8 \%$ (see Table 5.1). This could be associated with increased cultivated area among households who benefited from the InovAgro II project (1.9 ha for treatment communities versus 1.5 ha for control communities in 2015 , and 2.4 ha for treatment communities versus 2.3 ha for control communities), complemented with higher adoption rates of soybean, pigeon pea and maize improved seeds in treatment than control communities (9\% versus $5 \%$ for soybean, $5 \%$ versus $2 \%$ for pigeon pea, and $8 \%$ versus $5 \%$ for maize), potentially leading to increased labor demand at various stages of production. 
Table 5.1. Impact of the InovAgro II project on short-term outcome indicators

\begin{tabular}{|c|c|c|c|}
\hline \multirow{4}{*}{ Outcome variable } & \multicolumn{2}{|c|}{ Difference-in-Difference (DID) } & \multirow{4}{*}{$\begin{array}{l}\text { DID PSM } \\
\text { Model } 3 \\
\text { Coeff. } \\
\begin{array}{c}\text { Mean/ } \\
\text { (SE) }\end{array} \\
\end{array}$} \\
\hline & Model 1 & Model 2 & \\
\hline & Coeff. & Coeff. & \\
\hline & Mean/ (SE) & Mean/ (SE) & \\
\hline \multirow[t]{2}{*}{ Sold any crop from most recent season (1 = yes, 0 otherwise) } & 0.0490 & $0.0638^{* *}$ & $0.0758^{* *}$ \\
\hline & $(0.0330)$ & $(0.0323)$ & $(0.0330)$ \\
\hline \multirow[t]{2}{*}{ Sold soybean from most recent season ( 1 = yes, 0 otherwise) } & $0.0512^{* * *}$ & $0.0422^{* * *}$ & $0.0622^{* * *}$ \\
\hline & $(0.0158)$ & $(0.0157)$ & $(0.0158)$ \\
\hline \multirow[t]{2}{*}{ Sold pigeon pea from most recent season ( 1 = yes, 0 otherwise) } & $0.1479^{* * *}$ & $0.1522^{* * *}$ & $0.1678^{* * *}$ \\
\hline & $(0.0311)$ & $(0.0306)$ & $(0.0311)$ \\
\hline \multirow[t]{2}{*}{ Adopted improved seed for soybean ( 1 = yes, 0 otherwise) } & $0.0696^{* * *}$ & $0.0396^{* *}$ & $0.0724^{* * *}$ \\
\hline & $(0.0165)$ & $(0.0162)$ & $(0.0166)$ \\
\hline \multirow[t]{2}{*}{ Adopted improved seed for pigeon pea ( 1 = yes, 0 otherwise) } & $0.0253^{* *}$ & 0.0024 & $0.0217^{*}$ \\
\hline & $(0.0122)$ & $(0.0122)$ & $(0.0122)$ \\
\hline \multirow[t]{2}{*}{ Production value for soybean, pigeon pea and maize (thousand MZN) } & $61.4242^{* * *}$ & $68.0884^{* * *}$ & $70.7593^{* * *}$ \\
\hline & $(5.1769)$ & $(5.1759)$ & $(5.5243)$ \\
\hline \multirow[t]{2}{*}{ Access to output market information from formal sources ( $1=$ yes, 0 otherwise) } & $0.0540^{* *}$ & 0.0088 & $0.0417^{*}$ \\
\hline & $(0.0254)$ & $(0.0248)$ & $(0.0251)$ \\
\hline \multirow[t]{2}{*}{ Hired labor for any farming activity ( $1=$ yes, 0 otherwise) } & $0.0931^{* * *}$ & $0.0582^{* *}$ & $0.0962^{* * *}$ \\
\hline & $(0.0286)$ & $(0.0282)$ & $(0.0286)$ \\
\hline Other control variables & No & Yes & Yes \\
\hline Observations & 3,579 & 3,579 & 3,576 \\
\hline
\end{tabular}

Source: Authors' computation based on InovAgro II baseline (2015) and midline (2017) datasets.

Note: Standard errors in parentheses. Statistical significance test where $* * *$ is $<=1 \%, * *$ is $5 \%$ and $*$ is $10 \%$ level of significance. 


\section{Impact of the InovAgro II project on long term outcome variables}

Table 5.2 summarizes the impacts of the InovAgro II project on long term outcome variables. This table illustrates that when we do not control for covariates that could affect difference in trend or selection bias, exposure to the InovAgro II project has a significant positive impact on temporary migration of the household head or spouse, number of temporary migrants in the household and whether or not the household head or spouse has nonfarm activity as a primary or secondary activity. However, after controlling for the above-mentioned covariates, the impact of the InovAgro II project on these outcome variables becomes insignificant. On the other hand, as a result of exposure to the InovAgro II project, the asset index for all functioning assets and for functioning durable assets are higher among households in the treatment communities than among those in the control communities. Although not consistent across all three econometric approaches and all asset indices we employed, this positive impact of exposure to the InovAgro II project on asset index is consistent with findings presented earlier showing that the InovAgro II project resulted in a higher share of households selling soybean and pigeon pea, a higher adoption rate of soybean and pigeon pea improved seed, and increased total value of production for soybean, pigeon pea and maize. 
Table 5.2. Impact of the InovAgro II project on long-term outcome indicators

\begin{tabular}{|c|c|c|c|}
\hline \multirow{4}{*}{ Outcome variable } & \multicolumn{2}{|c|}{ DID } & \multirow{3}{*}{$\begin{array}{l}\text { DID PSM } \\
\text { Model } 3 \\
\text { Coeff }\end{array}$} \\
\hline & Model 1 & Model 2 & \\
\hline & Coeff & Coeff & \\
\hline & Mean/ (SE) & Mean/ (SE) & Mean/ (SE) \\
\hline \multirow[t]{2}{*}{ Had a temporary migrant head or spouse ( $1=$ yes, 0 otherwise) } & $0.0447^{*}$ & 0.0157 & 0.0214 \\
\hline & $(0.0262)$ & $(0.0258)$ & $(0.0260)$ \\
\hline \multirow[t]{2}{*}{ Number of temporary migrants } & $0.0930^{*}$ & 0.0580 & 0.0499 \\
\hline & $(0.0476)$ & $(0.0459)$ & $(0.0477)$ \\
\hline \multirow[t]{2}{*}{ Head or spouse with nonfarm primary or secondary activity ( $1=$ yes, 0 otherwise) } & $0.0916^{* * *}$ & 0.0379 & 0.0364 \\
\hline & $(0.0332)$ & $(0.0318)$ & $(0.0330)$ \\
\hline \multirow[t]{2}{*}{ Asset index - functioning items } & $0.1123^{*}$ & 0.0662 & $0.1300^{*}$ \\
\hline & $(0.0668)$ & $(0.0627)$ & $(0.0672)$ \\
\hline \multirow[t]{2}{*}{ Asset index - including non-functioning items } & 0.1000 & 0.0488 & $0.1278^{* *}$ \\
\hline & $(0.0648)$ & $(0.0600)$ & $(0.0651)$ \\
\hline \multirow[t]{2}{*}{ Asset index - only functioning durable items } & $0.1650^{* *}$ & $0.1099^{*}$ & $0.1628^{* *}$ \\
\hline & $(0.0662)$ & $(0.0631)$ & $(0.0665)$ \\
\hline \multirow[t]{2}{*}{ Asset index - including non-functioning durable items } & $0.1461^{\star *}$ & 0.0907 & $0.1592^{* *}$ \\
\hline & $(0.0636)$ & $(0.0598)$ & $(0.0637)$ \\
\hline Other control variables & No & Yes & Yes \\
\hline Observations & 3,579 & 3,579 & 3,576 \\
\hline
\end{tabular}

Source: Authors' computation based on InovAgro II baseline (2015) and midline (2017) datasets.

Note: Standard errors in parentheses. Statistical significance test where $* * *$ is $<=1 \%$, $* *$ is $5 \%$ and $*$ is $10 \%$ level of significance. 


\section{CONCLUDING REMARKS}

About $80 \%$ of the Mozambican population is employed in the agricultural sector and about $70 \%$ of the total country population lives in rural areas where agriculture is the main livelihood strategy. Coupled with low agricultural productivity, ensuring improvements in agricultural productivity is vital to increasing income and reducing poverty, which was estimated to be $46.1 \%$ in 2015 , with a higher poverty incidence in rural than in urban areas (50.1\% versus 37.4\%). Launched in 2010 and now in its third phase, the InovAgro project - funded by SDC and implemented by DAI in partnership with COWI - aims to increase incomes for poor smallholder farmers in northern Mozambique through improved agricultural productivity and participation in selected high-potential value chains, including maize, soybean, pigeon pea, sesame and groundnut. The InovAgro project's primary approach for achieving impact is by promoting the development of inclusive and sustainable market systems - also known as the Market System Development (MSD) approach — such that the impact of the InovAgro project interventions is felt long beyond the termination of the project.

In this paper, we evaluated the impact of the InovAgro project on short- and long-term outcome variables at the household level using two rounds of panel data collected by IFPRI: the baseline survey in 2015 covering the 2014/2015 agricultural season and midline survey in 2017 covering the 2016/2017 agricultural season. Although the InovAgro project is currently active in eleven districts in northern Mozambique and five high-potential value chains, the impact evaluation presented here examines two districts in Zambézia province (Alto Molócue and Molumbo) and two high-potential value chains (soybean and pigeon pea). Household-level DID and PSM findings reveal that exposure to the InovAgro project has a positive impact on short-term outcome variables, but limited impact on long-term outcome variables. This finding is expected given that the impact evaluation covers two years -- a short period of time to bring about the long-term impacts expected to eventually emanate from a Market System Development (MSD) project.

\section{Ways forward:}

- Impact evaluation programs of such market systems development (MSD) projects should be planned with longer period (baseline to endline) - especially, to investigate any potential impacts of such projects on income, productivity and overall welfare of small holders (that take longer period to have any of influence)

- Given the challenges to the sampling and survey implementation, as well as programmatic changes, adopting mixed methods approach (adopted in this study unlike the initial plan of using Randomized Control Trails - RCT) provides enough flexibility to cope with such design and programmatic changes in assessing the impact of such projects

- Though channeling the service provision through private sector (instead of direct intervention as it was the case during INOVAGRO-I) helps maintain the sustainability of the intervention, future implementation of this type of projects should focus on better coordination (training) of the service providers (private sector) and concerned government officers at all level (prior to and during the impact evaluation process) to enhance understanding and proper implementation of the impact evaluation design and monitoring capacity. 


\section{REFERENCES}

Abadie, A. 2002. "Bootstrap Tests for Distributional Treatment Effects in Instrumental Variables Models,"JASA, 97, 284-292, 231-263.

Angrist, J. and Pischke, J. 2008. Mostly Harmless Econometrics: An Empiricist's Companion. Princeton University Press. pp. 227-243. ISBN 978-0-691-12034-8.

InovAgro (Innovation for Agribusiness). 2014. The Early Signs of Impact - Final Terms of Reference.

-----. 2016. InovAgro Half Year Report: October 2015 - May 2016.

Erman, A., H. Ghebru, and T. Mogues. 2016. Access to Markets for Smallholder Farmers in Alto Molócue and Molumbo, Mozambique: Baseline Report of a Survey Conducted as Part of an Impact Evaluation of the InovAgro II Project. International Food Policy Research Institute.

Osorio-Cortes, Luis E., and Mark Lundy. 2018. Behaviour Change Scale-Up in Market Systems Development: A literature review. Working paper. Policies, Institutions and Markets (PIM), CGIAR.

Ravallion, M. 2007. Evaluating Anti-Poverty Programs. In Handbook of Development Economics, ed. T. P. Schultz and J. Strauss. 4:3787-3846.

Smart, J., H. Ghebru, and T. Mogues. 2019. Access to Markets for Smallholder Farmers in Alto Molócue and Molumbo, Mozambique: Midline Survey Report of the INOVAGRO II Impact Evaluation Project. International Food Policy Research Institute.

White, H., 2013. The use of mixed methods in randomized control trials. New Directions for Evaluation, 2013 (138), pp.61-73. 


\section{ALL IFPRI DISCUSSION PAPERS}

All discussion papers are available here

They can be downloaded free of charge

INTERNATIONAL FOOD POLICY RESEARCH INSTITUTE

www.ifpri.org

\section{IFPRI HEADQUARTERS}

1201 Eye Street, NW

Washington, DC 20005 USA

Tel.: +1-202-862-5600

Fax: +1-202-862-5606

Email: ifpri@cgiar.org 